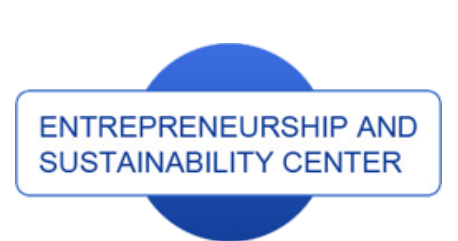

Publisher

enterprise

europe

network

Business Support on Your Doorstep

http://jssidoi.org/esc/home

\title{
METHODOLOGY APPROACH ON BENCHMARKING REGIONAL INNOVATION ON SMART SPECIALISATION (RIS3): A JOINT MACRO-REGIONAL TOOL TO REGIONAL PERFORMANCE EVALUATION AND MONITORING IN CENTRAL EUROPE*
}

\author{
Laima Gerlitz ${ }^{1}$, Christopher Meyer ${ }^{2}$, Gunnar Prause ${ }^{3}$ \\ ${ }^{1,2,3}$ University of Applied Sciences Wismar: Technology, Business and Design \\ Philipp-Müller-Str. 14, 23966 Wismar, Germany \\ ${ }^{2,3}$ Tallinn University of Technology \\ Ehitajate tee 5, 19086 Tallinn, Estonia
}

E-mails: ${ }^{1}$ laima.gerlitz@hs-wismar.de; christopher.meyer@hs-wismar.de; ${ }^{3}$ gunnar.prause@hs-wismar.de

Received 14 May 2020; accepted 8 November 2020; published 30 December 2020

\begin{abstract}
The current funding period of the European Union 2014 - 2020 advocates the application of the Smart Specialisation approach that has to be implemented on regional level. European NUTS-2 regions shall evaluate and reconsider their regional strategies for the upcoming funding period. Due to the high differences among the regions in terms of existing monitoring systems and policies, the performance measurement lacks a solid basis for a sufficient comparison, exemplification and transfer. In order to reduce this research gap, within this paper, the authors developed a comprehensible methodological tool using a given number of NUTS-2 regions with their distinctive monitoring systems and indicators in Central Europe. The benchmarking process is focusing on deploying existing performance indicators
\end{abstract}

\footnotetext{
" This research was supported by the Interreg project "SMART_watch" project that was implemented in the frame of the Interreg Central Europe Programme 2014-2020 from June 2017 to May 2020. The project is based on the research and practical gaps highlighting the needs to support and enhance monitoring capacity of the regions in terms of Smart Specialisation.
}
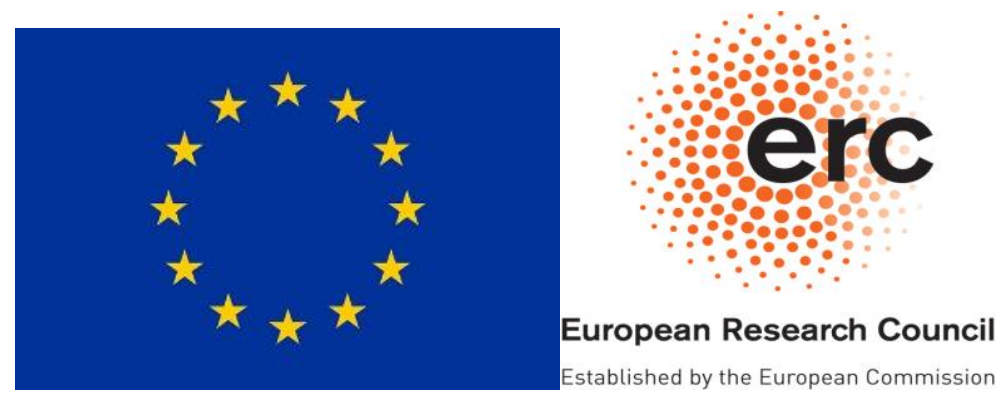


\section{ENTREPRENEURSHIP AND SUSTAINABILITY ISSUES}

ISSN 2345-0282 (online) http://jssidoi.org/jesi/

2020 Volume 8 Number 2 (December)

http://doi.org/10.9770/jesi.2020.8.2(80)

Make your research more visible, join the Twitter account of ENTREPRENEURSHIP AND SUSTAINABILITY ISSUES: @Entrepr69728810

from each regional strategy, analysing them and aiming at developing one common set of indicators. As a result, the developed methodology approach enables sufficient performance comparison in terms of RIS3 implementation in the current funding period on the one hand, and provides a crucial input for the future monitoring system design. As a result, the novel methodological tool yields contribution to both scholarly literature and practitioners. Furthermore, the benchmarking method provides various selection and combination options that allow direct insights in different fields' performance, such as regional spending to facilitate RIS3 implementation and Entrepreneurial Discovery process implementation as well. With this tool concerned, policy recommendations for the upcoming funding period and updates on the regional strategies can be drawn up.

Keywords: RIS3; Smart Specialisation; Benchmarking; Central Europe; Regional Innovation; Monitoring, Methodology; Common Set of Indicators

Reference to this paper should be made as follows: Gerlitz, L., Meyer, Ch., Prause, G. 2020. Methodology approach on benchmarking regional innovation on smart Specialisation (Ris3): a joint macro-regional tool to regional performance evaluation and monitoring in Central Europe. Entrepreneurship and Sustainability Issues, 8(2), 1359-1385. http://doi.org/10.9770/jesi.2020.8.2(80)

JEL Classifications: R11, R58, P25

\section{Introduction}

In a rapid pace of transformation (digital, policy and environment driven) Europe is facing with, sustainability is a key towards Europe's future. Strengthening capitalisation of Smart Specialisation gets even more importance, when it comes to sustainable development in Europe and worldwide. Smart Specialisation and Regional Innovation Strategies on Smart Specialisation (RIS3) were used to serve for implementation of the Europe 2020 strategy and its goals, among them to harness the potential for Smart Growth from targeted support to areas with investments, thus prioritising direction and contribution for achieving Smart Growth ((COM(2010) 546 final). It was also used to serve as a methodology contributing to Sustainable Development Goals (SDGs) of the UN in the EU Member States and countries outside the EU. Indeed, the futured European concept of Smart Specialisation for the next programming period 2021-2027 highlights the sustainability dimension, which is regarded as a key driver in achieving and sustaining European competitive edge, in line with the European Green Deal (COM(2019) 640 final).

Though, the implementation of the next-generation sustainability strategy for Europe, the so-called "European Green Deal" as the new growth strategy for the EU requires strong policy report and significant investment plans. Yet, little is said about specific steps on how the strategy should be implemented on local and regional levels. In this light, the integration of Smart Specialisation as an EU policy to demonstrate efforts and potentials towards place-based innovation achievements for transformation and secure sustainable development becomes significant (Larosse et al., 2020). In this light, a strong knowledge and experience back-up - evaluation and monitoring - are crucial for the forthcoming funding period of 2021-2027, where the EU expects better performance and advancement of regional innovation. Therefore, monitoring is a key delivering relevant information base, supporting policy decision making and facilitating stakeholders' and citizens' engagement (Gianielle \& Kleibrink. 2016, p. 95; Kleibrink et al., 2016, p. 1438; Mehta et al. 2019; Mazzanti et al., 2020; Mazzoni, 2020, Cismas et al., 2020; Khan et al. 2020). From the future perspective, this makes the current research very topical, as monitoring allows to counter measurement or steering related actions if they appear not to meet future perspectives.

Despite the recognised value of monitoring and evaluation within Smart Specialisation policy, in which monitoring and evaluation mechanisms build up the so-called $6^{\text {th }}$ step of the RIS3 methodological framework, the related literature remains still scattered. Only few research and policy paper tracks support unfolding literature on RIS3 evaluation and monitoring (Arnold, 2004; EC, 2014; Gianelle \& Kleibrink, 2015; Magro \& Wilson, 2013; Masana et al., 2019; Panori et al., 2020; Prause, 2014). Literature on design and modelling (Boschma, 2014; Woronowicz 


\section{ENTREPRENEURSHIP AND SUSTAINABILITY ISSUES}

ISSN 2345-0282 (online) http://jssidoi.org/jesi/

2020 Volume 8 Number 2 (December)

http://doi.org/10.9770/jesi.2020.8.2(80)

Make your research more visible, join the Twitter account of ENTREPRENEURSHIP AND SUSTAINABILITY ISSUES: @Entrepr69728810

et a., 2016) as well as implementation of Smart Specialisation, i.e. process-based approach, is mounting, whereas monitoring and evaluation related issues are scarce (Gianelle \& Kleinbrink, 2015). Indeed, this observation can be linked to an ex-ante conditionality the Smart Specialisation concept implies, where innovation policies are generated and implemented based on prioritised plans and follow in advance structured ways. Yet, monitoring and evaluation are crucial, as they foster policy learning, facilitate adaptation capability within a changing system, provide a solid basis for sustainable policy implementation (Aranguren et al. 2017; Gianelle \& Kleibrink, 2016; Kroll et al., 2014; Magro \& Wilson, 2015) and enable to reduce gaps in network structures (Virkkala et al., 2017).

Considering the fact that regional development remains at the core of each innovation policy, and regions should turn into learning ones by continuous improvement, knowledge region, facilitation of knowledge flow, ideas and learning (Florida, 1995, p. 532), monitoring and evaluation mechanisms appear to be crucial in order to make policy making in terms of Smart Specialisation solid and sustainable for the future (Kuznetsow \& Sabel, 2003). Bearing this in mind, the research is driven by this research problem of the missing link between Regional Innovation Strategies for Smart Specialisation and their monitoring and evaluation mechanisms. Indeed, the existing evidence underlines that linking monitoring to the strategy's intervention logic places a significant challenge for policy makers and public programme officers (Farole et al., 2011, p. 1107; Kleibrink et al., 2016, p. 1456). A challenging nature bears also availability of data and identification of indictors to measure as well as a shared understanding and action among involved stakeholders (Kleibrink \& Magro, 2018, p. 6). Indeed, indicators are important for sustainable development and planning performance measurement, thus implying positive changes at the end of the journey (Brugmann, 1997, p. 59). As a result, there is a huge emerging need for a systemic and holistic approach involving different governance mechanisms stakeholders.

Indeed, a marginalised focus on the monitoring and evaluation of RIS3 bears a rational academic and management practice-oriented researchers' response to provide a particular knowledge and data contribution in this rather porous research and policy field regarding RIS3. In that, the authors aim at giving more topical substance to RIS3 evaluation and monitoring by addressing and reducing the missing theoretical and practical foundations. When it comes to practice, evaluation and implementation of RIS3 on the regional level gets more blurred. Here, at is clearly stated, a common concept toward and a common set of indicators enabling benchmarking and thus monitoring of RIS3 on regional level are missing (Guzzo \& Perianez-Forte, 2019, p. 18). This finding clearly postulates the research gap. As a result, the present research tackles the place-bound research-to-practice gap, where missing conceptual frameworks on RIS3 evaluation and monitoring on the regional level on the one hand dovetail with management tools regarding practical RIS3 evaluation and monitoring marshalled on the other hand.

The literature delivers only a limited number of records setting about regional dimension of RIS3 evaluation and monitoring, in particular within the cross-border, macro-regional perspective (INTERREG) and applied research orientation (regional development, SMEs competitiveness) (Angelidou et al., 2017; Bagienska \& Rogowska, 2002; Woronowicz et al., 2016). Though, evaluation and monitoring efforts regarding RIS3 often remain in the design phase and usability of being deployed for tracing progress of RIS3 implementation is unexplored (Griniece et al., 2017, p. 4), followed by missing tools and methods reflecting the way in which the evaluation and monitoring can be used for the future policy revision and application (ibid., p. 6) and go beyond a narrow focus on meeting just audit requirements (Kleibrink et al., 2016, p. 1455). Finally, missing interlinking of policy approaches with theories frame the scientific research gap the authors want to address and reduce (Boschma, 2014; Foray et al., 2011).

The concerned research and practical management gaps were fuelled within the cross-border transnational (INTERREG) research project "SMART_watch" aiming at improving the links and between RIS3 monitoring and needs of end-users and involved stakeholders in RIS implementation. Within the framework of the Central Europe 


\section{ENTREPRENEURSHIP AND SUSTAINABILITY ISSUES}

ISSN 2345-0282 (online) http://jssidoi.org/jesi/

2020 Volume 8 Number 2 (December)

http://doi.org/10.9770/jesi.2020.8.2(80)

Make your research more visible, join the Twitter account of ENTREPRENEURSHIP AND SUSTAINABILITY ISSUES: @Entrepr69728810

Programme 2014-2020, the authors acting as work package leader for the design of policy recommendations pertaining to RIS3 evaluation and monitoring and future path of development. The research target groups include governance actors, like policy makers, triple or quadruple helix approach stakeholders (academia \& research, government, industry and society) as well as current and potential users of RIS3, namely Small and Medium-Sized Enterprises (SMEs) and other businesses that build up the backbone of the regional economy. In this nexus, the present research raises two research question:

1) How to compare and benchmark RIS3 performance of individual NUTS-2 regions within one European macro-region to enable cohesive and integrative future regional development driven by innovation?

2) How can a viable macro-regional and harmonised methodological and conceptual tool be constructed for comparison and benchmarking of individual NUTS-2 regions' performance in RIS3 implementation that goes beyond individual quantitative monitoring systems and indicators in Central Europe?

As a result, using the empirical data from the participating Central Europe regions within the "SMART_watch", the researchers aim at developing qualitative conceptual and methodological frameworks that facilitate and enable policy actors and other stakeholders to undertake evaluation and monitoring of RIS3 implementation and equip them with toolkit enabling a reasonable decision-making. In particular, the authors propose a so-called common set of indicators dedicated to enable evaluation of RIS3 performance in a macro-regional perspective. In addition, the research proposes a benchmarking tool that can be transferred to and employed to other European regions. Indeed, the recent research is calling for more qualitative approaches and their use in participatory evaluation and monitoring (Kleibrink \& Magro, 2018, p. 6). It is about harmonising conceptual frameworks and practical tools across EU NUTS 2 regions and making them functional in practice, thus empowering human capabilities to increase effectiveness of design and monitoring procedures in the future. By aiming at delivering the answer to the research question, the authors dovetail the research goals with the largely marginalised theoretical setting, which underpins the research scope and scale (evaluation and monitoring of the RIS3 implementation). Afterwards, the paper proceeds with the methodological considerations that are followed by comprehensive result presentation and discussion. Finally, implications for governance and stakeholder bodies involved in RIS3 evaluation and monitoring are displayed as well as research body on this particular field enhanced.

\section{RIS3 evaluation and monitoring in policy and theory nexus}

The overwhelming literature on Smart Specialisation, RIS and Innovation in Europe belong to the key building blocks that drive currently both researchers and practitioners. Yet, since Smart Specialisation refers to "policy running ahead of theory" (Foray et al., 2011, p. 1), academic approaches towards the conceptualisation have been so far highly marginalised, thus leading to missing manifestation of the concepts in the theoretical realm. Indeed, paramount scientific contributions on Smart Specialisation and RIS3 deliver rather policy-driven contributions that lack the dovetailing of the research with the existing and developing theories (Boschma, 2014; Fellnhofer, 2017). Paradoxically, as further development of RIS3 is subject to review for future improvements, current discourses shall highly demand strong proved theoretical foundations and not only focus on practice-driven approaches. In this regard, as well as with the aim to support topical discussion on RIS3 implementation evaluation and monitoring, the authors call for a solid systematic understanding deploying a bunch of applicable existing concepts and theories. For that reason, the researchers adopt a novel approach in the literature review of this paper by, first, conceptually linking up the intertwined policy discourses on RIS3 evaluation and monitoring province with applicable theoretical 


\section{ENTREPRENEURSHIP AND SUSTAINABILITY ISSUES}

ISSN 2345-0282 (online) http://jssidoi.org/jesi/

2020 Volume 8 Number 2 (December)

http://doi.org/10.9770/jesi.2020.8.2(80)

Make your research more visible, join the Twitter account of ENTREPRENEURSHIP AND SUSTAINABILITY ISSUES: @Entrepr69728810

treatises, and, second, providing a comprehensive but a simplified matrix with applicable theories that support and links research scope and scale through keywords.

\subsection{Positioning RIS3 evaluation and monitoring in policy discourses}

In order to make European economy more competitive against economies of US, Japan and other emerging world regions, such as China and South-East Asia, Europe made further attempts in advancing Europe's performance and regional development with the proposed strategy on smart, sustainable and inclusive growth in Europe - Europe 2020 strategy by the EC, followed by recent agendas to advance manufacturing and key enabling technologies "For a European Industrial Renaissance" (EC, 2014), and to prioritise community and customer experience in European innovation policy (EC, 2015). In this light, Smart Specialisation concept has moved from focusing solely on Research \& Development (R\&D) array towards a more networked approach, based rather on specific EU policy areas prioritisation and achievement of specific targets with the Europe 2020 strategy.

More than last three decades, discourses on Regional Innovation Systems (RIS) and strategic approaches towards Regional Innovation are ruling scholarly discourses as well as practical papers. A myriad of research papers and studies have evolved to underline the increasing role of innovation for European economy, in particular, cohesion, competitiveness and growth by means of RIS (Asheim et al, 2007; Asheim and Isaksen, 2002; Cooke \& Morgan, 1997, Cooke, 2001). Following regional innovation agendas, in 2007-2008 a concept of "Smart Specialisation" was born, which addresses realisation of the European Research Area by means of development of specialised clusters, agglomeration of knowledge resources and building knowledge hubs, accompanied by policy and institutional reforms. It was launched by a team of experts working for the European Commission (EC) with the aim to provide new ways for recovery of European economy from the economic crisis and acceleration of European integration, including reduction of differences, assurance of more balanced evolvement of European regions as well as creation of the right conditions for competition and cooperation (EC, 2009; Foray et al., 2009; Giannitsis \& Kager, 2009).

Smart Specialisation yields integration of various stakeholders from both public and private sector and postulates a complex multi-level governance. In the current funding period of 2014-2020, a concept of "Smart Specialisation" enjoys a growing interest on the European agenda, especially in order to safeguard sustainable and accountable use of EU Structural Funds (Iammarino et al., 2018), advance an outdated perception of regional innovation policy (Landabaso, 2014) and to bring more structured and legitimised way of proceeding by distributing EU funds (Foray, 2014; Kroll, 2019; McCann \& Ortega-Argiles, 2013, 2015, 2016a, 2015b, 2015c) as an ex-ante conditionality for involved stakeholders (Griniece et al., 2017; Kroll, 2015; Martinez-Lopez \& Palazuelos-Martinez, 2015). Not to forget, it is intended to streamline an interplay and coordination of the involved actors and stakeholders (Grillitsch, 2016; Larrea et al., 2919; Morgan, 2017; Panori et al., 2017).

Although evidence on Smart Specialisation and its growing popularity among policy makers is tremendous, majority of topical research and policy records appear to be circled around smart specialisation strategies and foresight (Paliokaite et al., 2015; Piirainen et al., 2017), consideration of place-based approaches (Kroll, 2015; Magro \& Wilson, 2019) the role of institutions (Grillitsch, 2016), involvement of different level of governance (Arangunen et al., 2019) and regional institutional frameworks (Mazzucato, 2014; Krammer, 2017; Rodriguez-Pose et al., 2014). Within the evaluation and monitoring dimension of the EU RIS3 methodological framework, the key research streams also confirm the distribution of the keywords pertaining to governance, institutions, cooperation, collective learning, resource pooling and discovery. When it comes to the overview of keywords and their tailoring to specific theoretical approaches, concepts and theories, the following Table 1 heralds the key concepts driving the specific RIS3 area - evaluation and monitoring and their principal allocation to key theoretical foundations. 


\section{ENTREPRENEURSHIP AND SUSTAINABILITY ISSUES}

ISSN 2345-0282 (online) http://jssidoi.org/jesi/

2020 Volume 8 Number 2 (December)

http://doi.org/10.9770/jesi.2020.8.2(80)

Make your research more visible, join the Twitter account of ENTREPRENEURSHIP AND SUSTAINABILITY ISSUES: @Entrepr69728810

Table 1. Conceptual Keywords and their Provinces Driving RIS3 Evaluation and Monitoring Discourses

\begin{tabular}{|c|c|c|c|c|}
\hline Keyword & $\begin{array}{l}\text { Application } \\
\text { Field }\end{array}$ & Application Meaning / Value & Conceptual Province & Research Record \\
\hline $\begin{array}{l}\text { (Re-) Definition of } \\
\text { RIS3 outputs }\end{array}$ & $\begin{array}{c}\text { Academics } \\
\text { Policy makers } \\
\text { Businesses }\end{array}$ & $\begin{array}{l}\text { RIS3 governance improvement for } \\
\text { future }\end{array}$ & $\begin{array}{l}+ \text { Balanced scorecard } \\
+ \text { Business model } \\
\quad \text { innovation }\end{array}$ & + Panori et al. (2020) \\
\hline $\begin{array}{l}\text { Decision-making } \\
\text { (evidence-driven) }\end{array}$ & Policy makers & $\begin{array}{l}+ \text { Strategic RIS3 management } \\
+ \text { RIS3 revision } \\
+ \text { Reducing information asymmetry, } \\
\text { uncertainty and risk }\end{array}$ & $\begin{array}{l}+ \text { Decision theory } \\
+ \text { Principal-agent } \\
\text { theory } \\
+ \text { Game theory }\end{array}$ & $\begin{array}{l}+\begin{array}{l}\text { Kleibrink et al. } \\
(2016)\end{array} \\
+ \text { Panori et al. }(2020)\end{array}$ \\
\hline $\begin{array}{l}\text { Participatory } \\
\text { policy making and } \\
\text { cooperation }\end{array}$ & $\begin{array}{l}\text { Academics } \\
\text { Policy makers } \\
\text { Businesses }\end{array}$ & $\begin{array}{l}+ \text { Informing about policy responses } \\
+ \text { Ensuring accountability \& } \\
\text { transferability of results } \\
+ \text { Participatory and inclusive } \\
\quad \text { approaches towards stakeholders } \\
\end{array}$ & $\begin{array}{l}+ \text { Network-based } \\
\text { innovation theory } \\
+ \text { Open innovation }\end{array}$ & $\begin{array}{l}+ \text { Kleibrink et al. } \\
\text { (2016) }\end{array}$ \\
\hline $\begin{array}{c}\text { Entrepreneurial } \\
\text { Discovery Process } \\
\text { (EDP) }\end{array}$ & Businesses & $\begin{array}{l}+ \text { Strengthening user-driven innovation } \\
+ \text { Engagement new actors in the EDP } \\
+ \text { Open platforms for cooperation } \\
+ \text { Attraction of talents }\end{array}$ & $\begin{array}{l}\text { + Open innovation } \\
+ \text { User-driven } \\
\quad \text { innovation } \\
+ \text { Design thinking } \\
+ \text { Service design }\end{array}$ & $\begin{array}{l}+ \text { Cvijanovic et al. } \\
\quad(2020)\end{array}$ \\
\hline $\begin{array}{c}\text { Evaluation } \\
\text { methods and } \\
\text { criteria for RIS3 }\end{array}$ & Policy makers & $\begin{array}{l}+ \text { Means of learning \& improvement } \\
\text { for the future } \\
+ \text { Regional observation } \\
+ \text { Harmonised tools and data } \\
\quad \text { availability }\end{array}$ & $\begin{array}{l}+ \text { Organisational } \\
\text { learning } \\
+ \text { Absorptive capacity }\end{array}$ & + Pires et al. (2019) \\
\hline $\begin{array}{l}\text { RIS3 Priority } \\
\text { identification \& } \\
\text { investment } \\
\text { horizons }\end{array}$ & $\begin{array}{l}\text { Policy makers } \\
\text { Businesses }\end{array}$ & $\begin{array}{l}+ \text { Long-term prioritisation and } \\
\text { planning } \\
+ \text { Anticipating long-term industrial and } \\
\text { technological trends for } \\
\text { transformation \& emerging industries }\end{array}$ & $\begin{array}{l}+ \text { Strategic foresight } \\
+ \text { Decision theory } \\
+ \text { Transaction Cost } \\
\text { Theory }\end{array}$ & $\begin{array}{l}\text { + Ranga (2018) } \\
+ \text { Vezzani et al. (2018) }\end{array}$ \\
\hline $\begin{array}{l}\text { Policy learning } \\
\text { and stakeholder } \\
\text { communication }\end{array}$ & Policy makers & $\begin{array}{l}+ \text { Learning from failure } \\
+ \text { Learning about transformation } \\
+ \text { Sustainable self-improvement cycles } \\
+ \text { Building \& reinforcing trust and } \\
\quad \text { cooperation }\end{array}$ & $\begin{array}{l}\text { + Collective learning } \\
+ \text { Absorptive capacity } \\
+ \text { Path dependency }\end{array}$ & 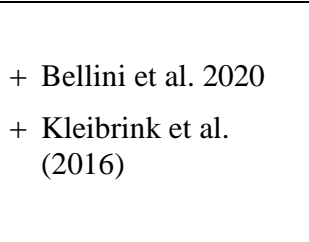 \\
\hline $\begin{array}{c}\text { Stakeholders } \\
\text { involvement and } \\
\text { coordination in } \\
\text { RIS3 }\end{array}$ & $\begin{array}{c}\text { Academics } \\
\text { Policy makers } \\
\text { Businesses }\end{array}$ & $\begin{array}{l}+ \text { Developing programme for RIS3 } \\
\text { monitoring improvement } \\
+ \text { Consultation, engagement and } \\
\text { bottom-up participation } \\
+ \text { Support economically weaker } \\
\text { regions with limited capacity for } \\
\text { RIS3 monitoring through open } \\
\text { engagement }\end{array}$ & $\begin{array}{l}+ \text { Network-based } \\
\text { innovation theory } \\
+ \text { Open innovation }\end{array}$ & $\begin{array}{l}+ \text { Magro et al. (2014) } \\
+ \text { McCann (2015) } \\
+ \text { McCann \& Ortega- } \\
\quad \text { Argiles (2016) }\end{array}$ \\
\hline
\end{tabular}

Source: Compiled by authors 


\section{ENTREPRENEURSHIP AND SUSTAINABILITY ISSUES}

ISSN 2345-0282 (online) http://jssidoi.org/jesi/

2020 Volume 8 Number 2 (December)

http://doi.org/10.9770/jesi.2020.8.2(80)

Make your research more visible, join the Twitter account of ENTREPRENEURSHIP AND SUSTAINABILITY ISSUES: @Entrepr69728810

The table above presents keywords and main concepts that are dominating in the literature and policy discourses when it comes to RIS3 evaluation and monitoring. The keywords and their interplay with the concepts and positioning with the theories are displayed in an alphabetic order not giving any specific weight to one or another. As this paper also serves for practical policy applications, it is intended to provide an overview and access to a basket key resources and theoretical foundations underpinning theoretical understanding.

\subsection{Positioning RIS3 evaluation and monitoring in theoretical setting}

The previous section contributes to embeddedness of the current research within the discourses of RIS3 evaluation and monitoring. In contrast to a myriad number of papers that deal with RIS3 and touch upon different aspects of RIS3, this paper concentrates on both understanding of RIS3 evaluation and monitoring from the conceptual and theoretical perspectives as well as delivering practical participatory tools. However, in order to easily trace and grasp key fundamental principles guiding RIS3 an especially its evaluation and monitoring is a colossal job. This is partly because of highly missing theoretical considerations in most of the scrutinised research literature, partly because of RIS3 standing for a highly complex phenomenon.

Innovation as the backbone of RIS3 is a theory and policy province showing intertwining of and integration with different concepts and theories. Because of its nature, innovation requires a tremendous understanding from different disciplines. Therefore, it is assumed that the most research misses a clear pinpointing of key applicable concepts and theoretical considerations by focusing mainly on general policy discussions. In order to facilitate the understanding and simplify the overview of the theoretical background, this present research has departed from the policy discussion and marshalling topical keywords that enable to trace the links with driving concepts and theories, innovation being the flagship and umbrella term. As a result, the authors of this paper argue, theoretical considerations can be circled around the following key building blocks bridging the gap in a comprehensive theoretical manifestation regarding RIS3 evaluation and monitoring, as compiled by the authors:

- Innovation (innovation generation, creative potential, openness, entrepreneurial discovery)

- Institutions, institutional arrangements and organisational culture (clusters, networks, hubs)

- Governance (multi-level horizontal cooperation, participatory inclusive stakeholder participation)

- Cognition, knowledge and learning (policy learning, participatory learning, absorptive capacity).

The core idea behind a systemic approach towards innovation is ex-ante strategic approach, a policy-driven way to spin off processes that enable both diversification, differentiation and new development paths. Already Schumpeter recognised the power of innovation for entrepreneurial activities by incessantly revolutionising economic structures in order to get better or more effective processes and products, the process known as "creative destruction". While doing so path dependency is an important precondition when defining strategy and patterns of organisational innovations (Schumpeter, 1947). Innovation and research in the 21 st century both are increasingly becoming international endeavours and most innovations originate from multiple sources, with many drawings in components or technologies developed in multiple locations (Hayek, 2002). Potential evolutionary pathway of this innovation system is dependent on inherent structures and existing dynamics that have to do with the adaptation of radical transformation (Foray et al., 2012). Indeed, within the RIS3 multiple streams of insights on innovation intertwin. Whereas in early discourses innovations were regarded as those emerging only in firms, networks and clusters as well as multi-level and multi-cultural communities became sources in innovation process and enabled to combine internal and external knowledge bases (Pavitt 1984; Chesbrough 2003; Cooke, 2016; Asheim \& Gertler 2005; Malerba 2005; Prause \& Thurner 2014), approach actors at various spatial scales (Smith 2000; Tödtling et al. 2006), maintain different types of interactions and transfers (Gilsing et al. 2011) and focus on locally available capacities 


\section{ENTREPRENEURSHIP AND SUSTAINABILITY ISSUES}

ISSN 2345-0282 (online) http://jssidoi.org/jesi/

2020 Volume 8 Number 2 (December)

http://doi.org/10.9770/jesi.2020.8.2(80)

Make your research more visible, join the Twitter account of ENTREPRENEURSHIP AND SUSTAINABILITY ISSUES: @Entrepr69728810

and capabilities (Gertler \& Levitte 2005; Boschma \& Ter Wal 2007). As a result of differentiating socio-economic setting in Europe and especially on the regional level, in order to accelerate innovative capacity and overcome socio-economic obstacles there emerged a stronger need to address local and regional challenges (Courchene 1995; Porter 2000; Wolfe 2002).

By addressing key existing challenges in Europe, experts advocated use of smart specialisation process, i.e. particularise knowledge base in European regions (Foray \& van Ark, 2008, p. 14). Actually, the idea of knowledgebased growth can be traced back also to learning and specialisation, which implies an interlinkage with the birth of evolutionary economics pointing out specialisation and learning as key drivers, e.g. within Adam Smith's "Wealth of Nations". Followed by profound treatises bridging learning and specialisation, like that of Schumpeter (1947), knowledge, technology and innovation are key sources enabling place-based specialisation (Fagerberg et al., 2004, Tiits et al., 2015; Ferreira \& Seixas, 2019). In this light, an institutional perspective is important, since institutions play a crucial role in facilitating learning, knowledge spill-overs and specialisation itself. The key current challenges that jeopardise RIS3 evaluation and monitoring pinpoint a lack of matching needs between regional governance and actors involved in innovation discovery processes, lack of implementation of bottom-up approaches enabling participatory processes, lack of capability to design and implement RIS3 policies as well as capability to engage actively in the processes of entrepreneurial discovery (Capello \& Kroll, 2016, p., 1397).

Indeed, local and regional challenges have been increasingly addressed by deploying the concept of RIS and clusters, which have seen a high rise among the place-based concepts (Aranguren et al., 2019). On the one hand, these concepts are bound to prevailing market forces, on the other hand, they presuppose a clear intertwining with the province of governance (Sotarauta, 2018). Indeed, in order to enable a smooth RIS3 implementation, actors from different sectoral arrangements are involved, like academic \& research, policy, businesses (entrepreneurs) and society in large (quadruple helix-approach). Furthermore, a smooth RIS3 implementation is deemed to be bound to interaction and intra-institutional interplays among regional, national, supra- and subnational levels. Moreover, an efficient governance is deemed to be bound to path dependency. Certainly, when it comes to governance improvement for RIS3 evaluation and monitoring, ex-ante experiences gathered are crucial in shaping future decisions and future monitoring mechanisms (Aranguren et al., 2019; Boschma, 2015).

Governance easiness and level thereof is highly dependent on the institutional thickness and territorial capital. The last one makes a clear interlinkage to capacity and capabilities of institutions, which, in turn, are highly dependent on knowledge base and absorptive capacity (Cohen \& Levinthal, 1990) or collective learning (Bellini et al, 2020). In this matter, absorptive capacity is crucial not only for RIS3 implementation but also for absorbing supply of research and innovation by local enterprises (SMEs) when designing and undertaking RIS3 evaluation and monitoring. In the same vein, the dovetailing of supply and demand sides, e.g. academic \& research with local and regional SMEs and their needs might have a huge impact on the desire and ability of both sectors to work in the future (Kempton et al., 2013, p. 14). Certainly, lack of absorptive capacity for new knowledge and innovation as well as missing articulation of demand frequently results in less-innovative regions. It limits capacity and capabilities to access, acquire and apply new and external knowledge, cross-fertilise and making use of it on the market (Asheim et al., 2017, p. 9; Barzotto et al., 2019, p. 215). In fact, lack of strong governance structures and thin institutions without strong industrial clusters, networks and industry associations capable to supply with the needed information, knowledge and inputs (Fotakis et al., 2014, p. 35). In this regard, governance is crucial for connecting or reconnecting participants in RIS3 implementation to enable following evaluation and monitoring, as smooth cooperation among them is a key precondition for delivery of innovative, desirable and sustainable innovation outputs as well as generate a shared value. In addition, the integration of policy makers and experts within this dialog is also persuasive. 


\section{ENTREPRENEURSHIP AND SUSTAINABILITY ISSUES}

ISSN 2345-0282 (online) http://jssidoi.org/jesi/

2020 Volume 8 Number 2 (December)

http://doi.org/10.9770/jesi.2020.8.2(80)

Make your research more visible, join the Twitter account of ENTREPRENEURSHIP AND SUSTAINABILITY ISSUES: @Entrepr69728810

An overview of key theoretical concepts applicable for RIS3 evaluation and monitoring reveal that key challenges' blocks result from thin institutions and institutional arrangements covering governance, cognition and innovation processes. At the core of the challenging nature, there shall be discussed social aspects of actors' interactions pertaining to value delivery, shared value principals, leadership, asymmetric information flows, uncertainty, ambiguity, volatility, opportunism, bargaining power as well as transaction and monitoring costs issues. As a result, the authors call for the future research to build upon sound theoretical foundations, e.g. New Institutional Economies and related concepts and put the topic of RIS evaluation and monitoring in the tailored theoretical framework that enables to find practical challenge and problem-solving solutions.

\section{Methodology}

In the present research, the authors set out to forge a methodological / conceptual tool that supports RIS3 evaluation and monitoring on a macro-regional level by provide a practical method for benchmarking RIS3 implementation performance across the regional boundaries, i.e. by providing a harmonised tool. By scrutinising the topical literature, the researchers highlight that RIS3 evaluation and monitoring is to a great extent lacking conceptual foundations. As a result, the study applies hybrid research approach (Fereday \& Muir-Cochrane, 2006, p. 80). Hereby, a combination of both inductive and deductive perspectives is done. From a deductive perspective, the research builds upon RIS3 evaluation and modelling approaches and traces key conceptual tenets. Subsequently, an inductive approach is used, since key insights from theory and practice are deployed to develop the methodological tool for practical applications. Indeed, the present research determines key building blocks and employs a specific structured approach by means of the developed outline (Fereday \& Muir-Cochrane, 2006, p. 80; Crabtree and Miller, 1992, pp. 93-109). As a result, a methodological framework (common set of indicators) is constructed that is used for analysis and measurement as a certain template.

The research journey (design) encompasses the following key steps:

- Participating in the applied research project "SMART_watch" as key researchers regarding RIS3 evaluation and monitoring as well as policy recommendations.

- Developing tools for data gathering and monitoring within the project context, where the project serves as an overall case study.

- Gathering data from all 10 participation NUTS-2 regions from RIS3 reports (cases).

- Conducting expert interviews and making field notes in the frame of the project events (2018-2019).

- Analysing the gathered data by using thematic analysis method, social network analysis and memos.

- Undertaking thematic analysis of RIS3 evaluation and monitoring discourses and its positioning within the context.

- Distilling research streams and locating applicable concepts on RIS3 evaluation and monitoring only.

- Providing conceptual meanings of RIS3 evaluation and monitoring in the policy and theoretical nexus.

- Synthesising, comparing, smoothing and amalgamating data and presenting research results - set of indicators as a methodological tool for macro-regional RIS3 performance benchmarking.

- Validating research results.

Furthermore, the present scholarship has chosen a qualitative research approach. As noted by Kleibrink \& Magro (2018), "there is still a long way to go to systematically cope with this issue. This opens up room for the use of more qualitative approaches of participatory monitoring and evaluation" (p. 6). By examining and interpreting data as well as determining key building blocks, the present research is able to comprehend the research phenomenon - 


\section{ENTREPRENEURSHIP AND SUSTAINABILITY ISSUES}

ISSN 2345-0282 (online) http://jssidoi.org/jesi/

2020 Volume 8 Number 2 (December)

http://doi.org/10.9770/jesi.2020.8.2(80)

Make your research more visible, join the Twitter account of ENTREPRENEURSHIP AND SUSTAINABILITY ISSUES: @Entrepr69728810

RIS3 evaluation and implementation within the regional discourses. With the qualitative research, a case study method is applied here (Yin, 2009, 2012), serving as an umbrella method and followed thematic analysis method (Braun \& Clarke, 2006). Given the nature of the case study, the case study can be referred to as "building block" study on a phenomenon identifying common patters (Thomas, 2011, p. 515). In this, the research in hand is explorative, at it aims at contributing to the research field (RIS3 evaluation and monitoring, which seems to be underdeveloped (Shields \& Rangarajan, 2013, pp. 26-27). In order to undertake an exploration, both integrative and interpretative syntheses techniques were introduced. Indeed, a synthesis has been achieved through pooling topical concepts in the research streams into higher-order conceptual approach (Dixon-Woods, 2005, p. 46).

In sum, it can be argued here that the present research was comprehensive, by addressing different aspects and combining diverse methodological perceptions applicable to the current research. Since the present research deals with innovation - a very complex phenomenon, research methodology needs also to underpin the comprehensive research nature. Yet, the authors made sound attempts in crystallising out research steps and endeavours.

\section{Data synthesis - a way towards developing collective methodological tool}

Reviewing the monitoring systems and especially the used indicators has shown, that the approaches in each participating region are overlapping in the methods. Namely, the following NUTS-2 regions were included in the analysis: Del-Alföld / Észak-Alföld (Ferenc et. al., 2013), Lubelskie (Sosnowski et. al., 2014), Mecklenburg Western Pomerania (Strategierat Wirtschaft - Wissenschaft, 2014), Piemonte (Regione Piemonte, 2016), Slaskie (Matusiewicz, 2012), Slovenia - Eastern (Republika Slovenija, 2014), Styria (Kohrgruber, s.a.) and Veneto (Regione del Veneto, 2015). Regarding the indicators, in most regions two different types are used: output and result indicators. The labels may differ, some regions use the terms of performance or strategy indicators, but the idea behind is equal. One category of indicators refers to the results of the RIS3 implementation. They try to measure the direct impact of the implementation for the whole region by using key indices for innovation, research or economics - often measure in percentage. In some cases, the Regional Innovation Strategy provides a base value from 2011 and a target value for 2020. While Mecklenburg-Western Pomerania only published base values for 2011, the region of Silesia doesn't use base and target values.

The second category of indicators are related to outputs. They measure project specific values and provide a certain amount as target value to be reached in the funding period 2014-2020. All regions follow the idea to use such kind of indicators, but their definition or actual label can differ widely. Those indicators can be number of patents, EU financed projects, persons employed in a specific sector, companies with new business products, cluster, $R \& D$ subsidies, supported networks and so on. In preparation of the common set, some overlapping indicators could be identified, but considering the working steps after developing the set, this kind of indicators may lead to high challenges in the benchmarking.

To develop a joined set of indicators, the authors follow a conceptualisation influenced by various articles, such as Yazday et. al. (2009), Shahin \& Mahbod (2007), Schwemlein et. al. (2016) and Maes et. al. (2016). In the first step, considered indicators have to be used at least in six regions. Since the indicators of the regions are not exactly labelled and measured the same. The resulting common set will be used as basic structure. In the second step, indicators which appear at least four and five times will be analysed individually. This second group can improve the amount and quality of the final set. But, for these indicators an explanation has to be provided to justify their contribution, since the amount of integration in the respective regions as reason is not feasible enough. 
ENTREPRENEURSHIP AND SUSTAINABILITY ISSUES

ISSN 2345-0282 (online) http://jssidoi.org/jesi/

2020 Volume 8 Number 2 (December)

http://doi.org/10.9770/jesi.2020.8.2(80)

Make your research more visible, join the Twitter account of ENTREPRENEURSHIP AND SUSTAINABILITY ISSUES: @Entrepr69728810

\section{Displaying research results: methodological framework and harmonisation endeavours}

As a result of research conducted, the authors analysed RIS3 documentation of 10 participating regions and provide the result overview in Table 2. The macro-regional indicator matrix, as showed in the table below, results from the comparison of the monitoring system in each region and the respective indicators. To create more add-value and flexibility regarding the upcoming benchmarking tool, the second set will be developed out of indicators, which are used by half of the regions. Both sets can be seen as final Common Set of Indicators.

The explained methodology leads in the first step to the following Table 2 with 15 indicators:

Table 2. Mapped Indicators in 10 analysed Central European regions

\begin{tabular}{|l|l|l|}
\hline \multicolumn{2}{|c|}{ Name of indicator } \\
\hline $\begin{array}{l}\text { Expenditures on R\&D at } \\
\text { universities on GDP }\end{array}$ & $\begin{array}{l}\text { Incidence of R\&D expenditure on } \\
\text { regional in GDP }\end{array}$ & $\begin{array}{l}\text { Private investments to facilitate } \\
\text { public support for R\&D }\end{array}$ \\
\hline $\begin{array}{l}\text { Expenditures on R\&D in private } \\
\text { sector on GDP }\end{array}$ & $\begin{array}{l}\text { Industrial SMEs introducing } \\
\text { innovations as \% of SMEs }\end{array}$ & $\begin{array}{l}\text { Private sector spending on R\&D as } \\
\% \text { of GDP }\end{array}$ \\
\hline $\begin{array}{l}\text { Expenditures on R\&D in public } \\
\text { sector and universities }\end{array}$ & $\begin{array}{l}\text { No. of businesses with product and } \\
\text { service innovations in \% of SMEs }\end{array}$ & $\begin{array}{l}\text { Public sector expenditure on R\&D } \\
\text { funded by business sector }\end{array}$ \\
\hline $\begin{array}{l}\text { Expenditures on R\&D in public } \\
\text { sector on GDP }\end{array}$ & $\begin{array}{l}\text { No. of companies supported \& } \\
\text { cooperate with research institutes }\end{array}$ & Scientific employees \\
\hline $\begin{array}{l}\text { Incidence of R\&D expenditure on } \\
\text { national GDP }\end{array}$ & $\begin{array}{l}\text { No. of patents and protection rights } \\
\text { granted to national entities }\end{array}$ & $\begin{array}{l}\text { Share of innovation-active } \\
\text { companies }\end{array}$ \\
\hline
\end{tabular}

Source: Compiled by authors

To improve this set, the authors highlight the following indicators, which are used in at least four or five regions of the project consortium's regions:

- Spending on innovation in companies in the industry and service sectors other than R\&D

- Share of R\&D employees in private sector

- Number of companies supported diversifying product portfolio

- Number of companies supported introducing new products to the market

- Increase in business innovation activities.

The listed indicators are highly related to the Entrepreneurial Discovery Process and are able to measure the performance of it in the regions. Entrepreneurial Discovery Processes are one of the main phases of implementing Smart Specialisation Strategies. It is seen as a potential specialisation in which the knowledge contributed by the entrepreneur does not concern a technical invention (Larosse, 2013). Rather, it will relate to a new area of specialisation beneficial for the locale, given its existing productive assets (Forey, 2012). To cover this crucial part of the implementation process, the mentioned indicators will be added to the Common Set.

Therefore, the suggested Common Set of Indicators can be listed as in Table 3 below:

With the derived Common Set of Indicators, the Benchmarking of the chosen regions can be implemented. The set is used as required database for the benchmarking. For regions, the necessary (and available) data was collected and 
ENTREPRENEURSHIP AND SUSTAINABILITY ISSUES

ISSN 2345-0282 (online) http://jssidoi.org/jesi/

2020 Volume 8 Number 2 (December)

http://doi.org/10.9770/jesi.2020.8.2(80)

Make your research more visible, join the Twitter account of ENTREPRENEURSHIP AND SUSTAINABILITY ISSUES: @Entrepr69728810

standardised to create one final index for comparison of the implementation of regional Smart Specialisation Strategies.

Table 3. Common Set of Indicators

\begin{tabular}{|l|l|l|l|}
\hline \multicolumn{4}{|l|}{ List of Indicators } \\
\hline $\begin{array}{l}\text { Expenditure on R\&D in } \\
\text { public sector and } \\
\text { universities }\end{array}$ & $\begin{array}{l}\text { Incidence of R\&D } \\
\text { expenditure on regional in } \\
\text { GDP }\end{array}$ & $\begin{array}{l}\text { No. of companies supported } \\
\text { and diversifying product } \\
\text { portfolio }\end{array}$ & $\begin{array}{l}\text { Private sector spending on } \\
\text { R\&D as \% of GDP }\end{array}$ \\
\hline $\begin{array}{l}\text { Expenditures on R\&D at } \\
\text { universities on GDP }\end{array}$ & $\begin{array}{l}\text { Increase in business } \\
\text { innovation activities }\end{array}$ & $\begin{array}{l}\text { No. of companies supported } \\
\text { and introducing new } \\
\text { products to the market }\end{array}$ & $\begin{array}{l}\text { Public sector expenditure on } \\
\text { R\&D funded by business } \\
\text { sector }\end{array}$ \\
\hline $\begin{array}{l}\text { Expenditures on R\&D in } \\
\text { private sector on GDP }\end{array}$ & $\begin{array}{l}\text { Industrial SMEs introducing } \\
\text { innovations as } \% \text { of SMEs }\end{array}$ & $\begin{array}{l}\text { No. of patents and protection } \\
\text { rights granted to national } \\
\text { entities }\end{array}$ & $\begin{array}{l}\text { Share of innovation-active } \\
\text { companies }\end{array}$ \\
\hline $\begin{array}{l}\text { Expenditures on R\&D in } \\
\text { public sector on GDP }\end{array}$ & $\begin{array}{l}\text { No. of businesses with } \\
\text { product and service } \\
\text { innovations in \% of SMEs }\end{array}$ & $\begin{array}{l}\text { Number of scientific } \\
\text { employees }\end{array}$ & $\begin{array}{l}\text { Share of R\&D employees in } \\
\text { private sector }\end{array}$ \\
\hline $\begin{array}{l}\text { Incidence of R\&D } \\
\text { expenditure on national } \\
\text { GDP }\end{array}$ & $\begin{array}{l}\text { No. of companies supported } \\
\text { institutes }\end{array}$ & $\begin{array}{l}\text { Private investments to } \\
\text { facilitate public support for } \\
\text { R\&D }\end{array}$ & $\begin{array}{l}\text { Spending on innovation in } \\
\text { companies in industry \& } \\
\text { service sectors other than } \\
\text { R\&D }\end{array}$ \\
\hline
\end{tabular}

Source: Compiled by authors

Additionally, we estimated a structure index covering the regional starting points in 2013 and 2014. This allows a better assessment of the final benchmarking index and comparison between relatively different regions.

Since the indicators are not available via one well-known dataset, scoreboard or scientific paper, different sources were taken into consideration for gaining necessary values. This also leads to different approaches to standardise the data as written in the following subchapters.

Following the idea of the methodology that yields to create a Common Set of Indicators, all indicators will be weighted depending on their frequency of use in the regions. Together with the normalised value, we receive a score for each indicator in all participating regions (ref. to Rickman \& Schwer, 1995). However, the final benchmarking index will be estimated by the mean of all scores, as shown in the equation:

$$
b_{r}=\frac{\sum_{i=0}^{n} m_{i} * x_{r i}}{n}
$$

where $b_{r}$ is the benchmarking index for the region $r, m_{i}$ describes the multiplier for the indicator $i$ and $\mathrm{x}_{\mathrm{ri}}$ the normalised value for indicator $i$ for the region $r$. The sum in the counter will be divided by the number of indicators $n$ to achieve the final benchmarking index for the region.

In the following subchapters, the methodology for the multiplier, the normalised values and the structure index will be explained in detail. 


\section{ENTREPRENEURSHIP AND SUSTAINABILITY ISSUES}

ISSN 2345-0282 (online) http://jssidoi.org/jesi/ 2020 Volume 8 Number 2 (December)

http://doi.org/10.9770/jesi.2020.8.2(80)

Make your research more visible, join the Twitter account of ENTREPRENEURSHIP AND SUSTAINABILITY ISSUES: @Entrepr69728810

\section{Indicator Multiplier}

Following the presented idea of collecting a common set for indicators to measure the implementation of Smart Specialisation Strategies, we can differ between different classes of indicators due to their frequency of appearance in the different regional monitoring systems. As an example, we want to take out the indicators "private sector spending on R\&D in percent of GDP" and "share of R\&D employees". While the first one is used as indicator for RIS3 implementation in all regions or is at least adoptable to one used indicator, the second one is only used in around $60 \%$. Therefore, the value of the first indicator will have a higher influence on the final benchmarking score due to the mentioned multiplier $m_{i}$. The following Table 4 shows the multiplier for every indicator of the common set:

Table 4. Common Set of Indicators

\begin{tabular}{|l|l|}
\hline \multicolumn{1}{|c|}{ Name of indicator } & Weight \\
\hline Expenditures on R\&D at universities on GDP & 1,2 \\
\hline Expenditures on R\&D in private sector on GDP & 1,2 \\
\hline Expenditures on R\&D in public sector and universities & 1,2 \\
\hline Expenditures on R\&D in public sector on GDP & 1,2 \\
\hline Incidence of R\&D expenditure on national GDP & 1,2 \\
\hline Incidence of R\&D expenditure on regional in GDP & 1,2 \\
\hline Increase in business innovation activities & 0,6 \\
\hline Industrial SMEs introducing innovations as \% of SMEs & 1,0 \\
\hline No. of businesses with product and service innovations in \% of SMEs & 1,2 \\
\hline No. of companies supported \& cooperate with research institutes & 1,2 \\
\hline No. of companies supported diversifying product portfolio & 0,6 \\
\hline No. of companies supported introducing new products to the market & 0,6 \\
\hline No. of patents and protection rights granted to national entities & 1,0 \\
\hline No. of scientific employees & 1,2 \\
\hline Private investments to facilitate public support for R\&D & 1,0 \\
\hline Private sector spending on R\&D as \% of GDP & 1,2 \\
\hline Public sector expenditure on R\&D funded by business sector & 1,2 \\
\hline Share of innovation-active companies & 1,0 \\
\hline Share of R\&D employees in private sector & 0,6 \\
\hline Spending on innovation in companies in the industry \& service sectors other than R\&D & 0,8 \\
\hline
\end{tabular}

Source: Compiled by authors

Basically, indicators that are taken into consideration in all regional monitoring system receive a multiplier of 1,2. The weights are fixed according to the amount of appearances (Berger \& Bristow, 2009). Whenever a region is missing, we subtract 0,2 , which means that a multiplier of 0,6 is given to an indicator, that is not used by three regions. 
ENTREPRENEURSHIP AND SUSTAINABILITY ISSUES

ISSN 2345-0282 (online) http://jssidoi.org/jesi/

2020 Volume 8 Number 2 (December)

http://doi.org/10.9770/jesi.2020.8.2(80)

Make your research more visible, join the Twitter account of ENTREPRENEURSHIP AND SUSTAINABILITY ISSUES: @Entrepr69728810

Introducing a multiplier helps to generate a more feasible final benchmarking score, since a good performance in an often-used indicator in monitoring systems is appreciated in the final score as well. On the opposite a low used indicator doesn't prosecute bad performance that much.

\section{Normalised Values for Indicators}

To yield comprehensible values for all indicators across the respective regions, the authors collected the necessary data through four different methods by using different data sources. All four ways of data gaining are presented in the following subchapters. However, the authors preferred the first option that follows directly the regional monitoring system of each region. Nevertheless, only a few normalised values could be taken out from this option. This results in a lack of information out of the regional strategy papers, which do not provide all necessary information to trace the idea of the respective region on how to get the data / values.

\section{Values from regional Smart Specialisation Strategy Documents}

By analysing the regional strategy documents in the frame of the development of a Common Set of Indicators, a collection of the used values for all regions was developed. In some regions, the responsible institutions for implementing the Smart Specialisation Strategy defined start and target value of the indicators used in the monitoring system for the current funding period. This allows an easy measurement of the implementation by comparing the defined target value for 2020 with the latest value, that is provided for the respective indicator. Having this in mind, the value $\mathrm{x}_{\mathrm{ir}}$ can be obtained as follows:

$$
x_{i r}=\frac{t_{i r}-s_{i r}}{y_{i r}-s_{i r}}
$$

where $t_{i r}$ and $s_{i r}$ are the target (2020) and starting value (2014) defined by the regions. $y_{\text {ir }}$ is the latest value the authors were able to collect for the respective indicator. Therefore, equation (2) describes the resulting value as rate of the difference between planned performance and actual performance. If the region is able to achieve the planned target value, the value for the indicator would be $x_{i r}=1$, while underperformance yields in $x_{i r}<1$. However, $\mathrm{x}_{\mathrm{ir}}>1$ is also a possible value, but it should be reminded, that the target values are defined for 2020 and the latest values are mostly accessible for 2018 , which means that the data demands a two years gap.

\section{Normalised Data via Regional Innovation Scoreboard 2019}

Since not all regions provide the necessary information to follow previous options and / or the strategy paper do not present the methodology how the data was normalised or from which sources it was taken, another option has to be considered to get the necessary data for a useful benchmarking.

As it is shown in the Annex I, some indicators of the common set can be represented via indicators that are used in the Regional Innovation Scoreboard. The scoreboard is provided by the European Commission on a yearly basis, by analysing the NUTS2 regions. This allows us, to use the latest available data from a validated data source (Hollanders et. al., 2019).

The Scoreboard provides three information to create the normalised values for the respective indicators. Therefore, we can use different approaches to obtain the demanded normalised value. The first option is used, whenever the Scoreboard provides the data in relation to the European and national level of the respective indicator:

$$
x_{i r}=\frac{\left(e_{i r}+l_{i r}\right) * 0,007}{2}
$$


Make your research more visible, join the Twitter account of ENTREPRENEURSHIP AND SUSTAINABILITY ISSUES: @Entrepr69728810

where $\mathrm{e}_{\mathrm{ir}}$ is the score taken out from the Regional Innovation Scoreboard for the respective region in relation to the European level and $l_{\text {ir }}$ the score in relation to national level. The values are multiplied with 0,007 , since we assume 0,7 as value for the mean performance in the frame of Smart Specialisation implementation. By dividing the score in the counter with 2 , we obtain the normalised value for the indicator of the respective region.

As second option, we use the provided value for some indicators, which are not related to European and National level. In this case, the mean of all European NUTS2 regions was calculated by the authors from the Regional Innovation Scoreboard. Having the European mean value and the regional value, we can obtain the normalised value for the benchmarking by using:

$$
x_{i r}=0,007 * \frac{z_{i r}}{m_{i}}
$$

where $z_{i r}$ is the value taken out from the Scoreboard and $m_{i}$ the calculated European mean for the respective indicator $i$. Again, we are multiplying 0,7 since we assume that this is the value for mean performance. This assumption follows the Lithuanian Ministry of Education and Science (2010) labelling $67-74 \%$ as an average performance.

\section{Normalised Data via Regional Competitiveness Index}

In addition to the Regional Innovation Scoreboard 2019, data from the Regional Competitiveness Index were used to fulfil the database for the benchmarking tool as shown in the Annex I. The Competitiveness Index is also a yearly provided source for NUTS regions to measure the competitiveness performance and readiness in business sectors (Annoni \& Dijkstra, 2019).

The Index provides a value for every European NUTS2 region. Therefore, the same method can be used as earlier in option two for the Regional Innovation Scoreboard. Therefore, we use again

$$
x_{i r}=0,7 * \frac{y_{i r}}{m_{i}}
$$

where $y_{i r}$ is the value taken out from Competitiveness Index and $\mathrm{m}_{\mathrm{i}}$ the calculated European mean of all regions for the respective indicator $i$. As mentioned before, we are multiplying 0,7 as value for mean performance.

\section{Normalised Data via EuroStat}

As third validated data source, EuroStat as official statistical institution of the European Commission located in Luxembourg was used to obtain the remaining data (European Commission, 2019). Once again, for every region and the respective indicator, a value could be taken out from the database. Therefore, the equation is nearly the same as before:

$$
x_{i r}=0,7 * \frac{a_{i r}}{m_{i}}
$$

where $\mathrm{a}_{\mathrm{ir}}$ is the value taken out from EuroStat and $\mathrm{m}_{\mathrm{i}}$ the calculated European mean of all regions for the respective indicator $i$. The fraction is multiplied with 0,7 due to the mentioned assumption of mean performance. 


\section{ENTREPRENEURSHIP AND SUSTAINABILITY ISSUES}

ISSN 2345-0282 (online) http://jssidoi.org/jesi/

2020 Volume 8 Number 2 (December)

http://doi.org/10.9770/jesi.2020.8.2(80)

Make your research more visible, join the Twitter account of ENTREPRENEURSHIP AND SUSTAINABILITY ISSUES: @Entrepr69728810

Normalised Data using a combination of data sources

For some indicators, none of the shown methods were feasible. This results in a lack of information / data or in the understanding of the indicators content. Therefore, the authors conduct for the following indicators an individual approach to obtain normalised data:

- Incidence of total R\&D expenditures on GDP.

To achieve a normalised value for this indicator, we use a combination of the previous shown methods. This includes data from the Regional Innovation Scoreboard and Eurostat. The equation is built as follows:

$$
x_{4 r}=\frac{\left(0,007 *\left(l_{5 r} * l_{6 r}\right)+x_{7 r}\right)}{3}
$$

where $l_{5 r}$ is the value from the Scoreboard in relation to national level for the indicator "expenditures on R\&D in private sector referring to GDP", $\mathrm{l}_{6 \mathrm{r}}$ the value from the Scoreboard in relation to national level for the indicator "expenditures on R\&D in public sector referring to GDP" and $x_{7 r}$ the value for "expenditures on R\&D at universities referring to GDP" taken from EuroStat by using the presented method.

\section{Incidence of $R \& D$ expenditures on regional GDP}

The normalised value for this indicator follows directly from the presented above. To obtain the normalised value additional data from the Regional Innovation Scoreboard is used.

$$
x_{3 r}=x_{4 r} * \frac{G D P_{n}}{G D P_{r}}
$$

where $\mathrm{GDP}_{\mathrm{n}}$ is the national and $\mathrm{GDP}_{\mathrm{r}}$ is the regional Gross Domestic Product taken out from the Regional Innovation Scoreboard. That means, we multiply the value for indicator No. 4 with the relation between national and regional GDP to obtain a normalised value for this indicator.

\section{Structure Index}

The Structure Index is based on an idea and tool published on the S3-platform by the European Commission. It tries to identify the characteristics in terms of structural conditions for the participating regions at the beginning of the Smart Specialisation funding period 2014 - 2020 (Navarro et. al. 2014). Those characteristics are seen as fixed in the short term and reflect the way innovation and economic evolution happen in the region. However, for the developed benchmarking tool described in this report, the provided structure benchmarking tool is not sufficient, since it shows the 35 nearest regions from all European NUTS2 regions to the selected one. This doesn't allow a comparison between the participating regions which are highly different what excludes them in the provided tool.

To solve this problem, we access the data from Regional Innovation Scoreboard and Regional Competitiveness Index. The database described for the European structure tool can be covered in a sufficient way by the two mentioned data sources. To obtain a structure index, we use the final scores from 2013 and 2014 from the data sources. Therefore, the structure index $u_{r}$ can be written as

$$
u_{r}=\frac{\left(R I S_{r}^{2013}+R C I_{r}^{2014}\right)}{2}
$$


ENTREPRENEURSHIP AND SUSTAINABILITY ISSUES

ISSN 2345-0282 (online) http://jssidoi.org/jesi/

2020 Volume 8 Number 2 (December)

http://doi.org/10.9770/jesi.2020.8.2(80)

Make your research more visible, join the Twitter account of ENTREPRENEURSHIP AND SUSTAINABILITY ISSUES: @Entrepr69728810

where, $\mathrm{RIS}_{\mathrm{r}}^{2013}$ is the total index score for the region from the Regional Innovation Scoreboard in 2013 and $\mathrm{RCI}_{\mathrm{r}}^{2014}$ is the total score for the region taken from the Regional Competitiveness Index.

\section{Methodological framework in practice - benchmarking RIS3 performance in Central Europe}

By using the described methodology, the research yields the following result table for the regions:

Table 5. Benchmarking results

\begin{tabular}{|l|c|c|}
\hline \multicolumn{1}{|c|}{ Region } & Structure Index & Benchmarking Index \\
\hline D./E.-Alföld & -0.19425 & 0.4841 \\
\hline Jihozápad & 0.1928 & 0.5383 \\
\hline Lubelskje & -0.1297 & 0.5135 \\
\hline Mecklenburg Western-Pomerania & 0.53495 & 0.6689 \\
\hline Piemonte & 0.3194 & 0.8307 \\
\hline Silesia & 0.05105 & 0.4425 \\
\hline Slovenia - Eastern & 0.3407 & 0.6158 \\
\hline Styria & 0.63685 & 0.8965 \\
\hline Veneto & 0.29255 & 0.6333 \\
\hline
\end{tabular}

Source: Compiled by authors

As best performing region Piemonte can be indicated with the highest performance value, followed by Styria and Mecklenburg Western-Pomerania. Latter regions have the highest Structure Index compared to all regions, but obviously lose their front positions to Piemonte, which is starting from an average point in the frame of the Structure Index with 0.3194. Slovenia - Eastern possesses a well comparable Structure Index with 0.3407, but can't provide the same level of performance according to the Benchmarking Index.

Furhermore, the regions Lubelskje and D./E.-Alföld provide a negative Structure Index due to the negative value taken from the Regional Competitiveness Index. However, both regions obtain an average score overtaking Silesia, which started with a value of 0.05105 and is indicated as region with the lowest performance.

In the following, we will edit the benchmarking in two scenarios to create an analysis on specific fields. We will compare the Benchmarking Index from Table 5 as standard value with the yielding index after editing. An increase of the Benchmarking Value leads to the interpretation that the respective region is under-performing in the chosen field, since we exclude low values. In return, if the Benchmarking Index decreases, we can assume that the respective region is well performing, since we excluded high values.

To provide a clearer performance measurement, the indicators related to the GDP shall be excluded. Due to their measurement, that is relying on spending compared to regional and / or national GDP, it could lead to a bias in the performance measurement. Therefore, the seven respective indicators are excluded to obtain the Benchmarking Index. Table 6 shows the results. 


\section{ENTREPRENEURSHIP AND SUSTAINABILITY ISSUES}

ISSN 2345-0282 (online) http://jssidoi.org/jesi/ 2020 Volume 8 Number 2 (December)

http://doi.org/10.9770/jesi.2020.8.2(80)

Make your research more visible, join the Twitter account of ENTREPRENEURSHIP AND SUSTAINABILITY ISSUES: @Entrepr69728810

Table 6. Benchmarking results after excluding GDP related indicators

\begin{tabular}{|l|c|c|c|}
\hline \multicolumn{1}{|c|}{ Region } & Structure Index & Benchmarking Index & $\begin{array}{c}\text { Benchmarking Index } \\
\text { (without GDP indicators) }\end{array}$ \\
\hline D./E.-Alföld & -0.19425 & 0.4841 & 0.4000 \\
\hline Jihozápad & 0.1928 & 0.5383 & 0.4985 \\
\hline Lubelskje & -0.1297 & 0.5135 & 0.3873 \\
\hline Mecklenburg Western-Pomerania & 0.53495 & 0.6689 & 0.5633 \\
\hline Piemonte & 0.3194 & 0.8307 & 0.6674 \\
\hline Silesia & 0.05105 & 0.4425 & 0.4396 \\
\hline Slovenia - Eastern & 0.3407 & 0.6158 & 0.6431 \\
\hline Styria & 0.63685 & 0.8965 & 0.7965 \\
\hline Veneto & 0.29255 & 0.6333 & 0.6235 \\
\hline
\end{tabular}

Source: Compiled by authors

Table 6 shows that only Silesia and Slovenia - Eastern can increase their score after excluding GDP-related indicators. The remaining regions suffer a decrease. The highest decrease can be seen for the region Piemonte, that leaded the first measurement with all indicators. The interpretation behind the realised scores is as follows, regions with a decreased score spend an amount of money to facilitate Smart Specialisation implementation that is not corresponding to the realised performance. On the other way around, those regions - Silesia and Slovenia - Eastern - have an over-performing related to their spending in relation to the GDP.

In another scenario, we exclude those indicators that are linked to Entrepreneurial Discovery Processes (EDP) (Larosse, 2013). As mentioned earlier, we identified five identified five indicators which are directly connected to EDP. Table 7 shows the yielded results.

Table 7. Benchmarking results after excluding EDP indicators

\begin{tabular}{|l|c|c|c|}
\hline \multicolumn{1}{|c|}{ Region } & Structure Index & Benchmarking Index & $\begin{array}{c}\text { Benchmarking Index } \\
\text { (without EDP indicators) }\end{array}$ \\
\hline D./E.-Alföld & -0.19425 & 0.4841 & 0.5526 \\
\hline Jihozápad & 0.1928 & 0.5383 & 0.6054 \\
\hline Lubelskje & -0.1297 & 0.5135 & 0.6057 \\
\hline Mecklenburg Western-Pomerania & 0.53495 & 0.6689 & 0.7804 \\
\hline Piemonte & 0.3194 & 0.8307 & 0.9556 \\
\hline Silesia & 0.05105 & 0.4425 & 0.4878 \\
\hline Slovenia - Eastern & 0.3407 & 0.6158 & 0.6758 \\
\hline Styria & 0.63685 & 0.8965 & 1.0321 \\
\hline Veneto & 0.29255 & 0.6333 & 0.6808 \\
\hline
\end{tabular}

Source: Compiled by authors 


\section{ENTREPRENEURSHIP AND SUSTAINABILITY ISSUES}

ISSN 2345-0282 (online) http://jssidoi.org/jesi/

2020 Volume 8 Number 2 (December)

http://doi.org/10.9770/jesi.2020.8.2(80)

Make your research more visible, join the Twitter account of ENTREPRENEURSHIP AND SUSTAINABILITY ISSUES: @Entrepr69728810

Those regions, that suffer from a decrease can be attested a good performance in EDP implementation since their high values are excluded in this scenario. However, only Lubelskje provides a mentionable decrease of the value and can be identified as best performing region in terms of EDP. In return, Styria, Piemonte and Mecklenburg Western-Pomerania provide the highest increase in their Benchmarking Index. The logical interpretation leads to an under-performance in terms of EDP in those regions, since we excluded low values measuring EDP.

\section{Conclusions}

The first research objective of this paper was to elaborate and analyse how a comparable benchmarking of NUTS2 regions for their Smart Specialisation implementation can be established as a crucial step for future regional development and innovation policies. Given the topicality of the transition to the new funding period and launch of European growth strategies such as the European Green Deal, monitoring and evaluation of RIS3 and its missing theoretical concepts and scientific foundation was analysed within the undertaken research. The introduced methodological framework including a common set of indicators steps in to the gap of missing collaborative approaches of European NUTS-2 regions.

As a second research objective, the paper in hand provides a conceptual and methodological tool for performance comparison of individual NUTS-2 regions RIS3 implementation. The conducted research analysed and elaborated the positioning of RIS3 monitoring in contrast with latest policy discourses and theoretical settings. So far, a unified concept as well as the link between Smart Specialisation policy approach and theoretical concepts for monitoring was missing. The tool fills in this gap and contributes to the current political discourse on innovation policy governances and policy learning for future Smart Specialisation Strategy development and implementation.

The benchmarking methodology is considered for a limited number of regions in the frame of the Regional Implementation on Smart Specialisation Strategies (RIS3). After a detailed review of the published regional strategy documents, the presented monitoring systems and their indicators were used for a comparison and measurement of the appearance for each indicator. We emphasised a set containing 20 indicators to measure Smart Specialisation.

To collect the necessary data, we focused on the provided measurement in the regional strategy documents. However, due to the fact, that regions partly did not provide detailed explanation how they collected the data (ref. to Ferenc et. al., 2013, Sosnowski et. al., 2014 and Strategierat Wirtschaft - Wissenschaft, 2014) we introduced a method to receive the necessary data from well-validated databases. To enlarge the result analysis, enable sufficient data interpretation and provide a better performance comparison, Structure Index of each regions are included, which shall cover the "starting point" for each region at the beginning of the Smart Specialisation funding period $2014-2020$.

By using the explained Benchmarking method, we received first results on the performance, indicating Piemonte with the highest value. After editing the set of indicators by excluding GDP related values, we provided the assumption, that except Silesia and Slovenia - Eastern have a spending to facilitate the implementation of Smart Specialisation, which is not corresponding to the measure outcomes / performance. This is a crucial insight in the development of political recommendations for adjustments of the current regional strategies.

Furthermore, we analysed the implementation of EDPs by editing the indicators. The result table has shown, that Lubelskje region is best-performing of the analysed regions. For the weak performing regions such as Silesia, Slovenia - Eastern and D./E.-Alföld the implementation of EDP in the funding period was not successful and should receive a higher focus in the development of the upcoming regional strategies. 


\section{ENTREPRENEURSHIP AND SUSTAINABILITY ISSUES}

ISSN 2345-0282 (online) http://jssidoi.org/jesi/

2020 Volume 8 Number 2 (December)

http://doi.org/10.9770/jesi.2020.8.2(80)

Make your research more visible, join the Twitter account of ENTREPRENEURSHIP AND SUSTAINABILITY ISSUES: @Entrepr69728810

The presented approach for Benchmarking provides a flexible methodology, which can be generalised on every NUTS-2 regions and even on smaller and larger scale. However, the methodology is limited in the number of regions that are considered to develop a set of indicators. Since regional development in terms of innovation and the regional policies behind are highly different, the methodology will not provide a sufficient set if the number of regions is too high. Nevertheless, it is a valid measurement to benchmark a certain number of different regions. The methodology may be used especially for neighbour regions to derive recommendations in the implementation processes and facilitate cross-border insights.

\section{References}

Angelidou, M., Komninos, N., Passas, I., Psaltoglou, A. \& Tsarchopoulos, P. (2017). Monitoring the Impact of Smart Specialisation Strategies across EU Regions. Proceedings of International Conference for Entrepreneurship, Innovation and Regional Development Conference, pp. 343-353, Thessaloniki, Greece.

Annoni, P. \& Dijkstra, L. (2019). The EU Regional Competitiveness Index 2019.

Aranguren, M.J., Morgan, K. \& Wilson, J. (2017). Implementing RIS3 - The Case of the Basque Country, Cuadernos Orkestra.

Aranguren, M.J., Magro, E., Navarro, M. \& Wilson, J. (2019). Governance of the territorial entrepreneurial discovery process: looking under the bonnet of RIS3, Regional Studies, 53(4), 451-461, https://doi.org/10.1080/00343404.2018.1462484

Arnold, E. (2004). Evaluating research and innovation policy: A systems world need systems evaluation. Research Evaluation, 13(1), 3-17.

Asheim, B., Grillitsch, M., \& Trippl, M. (2017). Smart specialization as an innovation-driven strategy for economic diversification:

Examples from Scandinavian regions. In Advances in the theory and practice of smart specialization (pp. 73-97). Academic Press.

Asheim, B. T., \& Isaksen, A. (2002). Regional innovation systems: the integration of local 'sticky' and global 'ubiquitous' knowledge. The Journal of Technology Transfer, 27(1), 77-86.

Asheim, B. \& Gertler, M. (2005). The geography of innovation, The Oxford handbook of innovation, pp. 291-317.

Asheim, B., Coenen, L., \& Vang, J. (2007). Face-to-face, buzz, and knowledge bases: sociospatial implications for learning, innovation, and innovation policy. Environment and planning C: Government and Policy, 25(5), 655-670.

Bagienska, A. \& Rogowska, P. (2020). Smart Specialisation Strategy - bibliometric analysis \& GoSmart BSR project practices. Academy of Management, 4(1), 90-105.

Barzotto, M., Corradini, C., Fai, F. M., Labory, S., \& Tomlinson, P. R. (2019). Enhancing innovative capabilities in lagging regions: an extra-regional collaborative approach to RIS3. Cambridge Journal of Regions, Economy and Society, 12(2), 213-232.

Bellini, N., Lazzeri, G., \& Rovai, S. (2020). Patterns of policy learning in the RIS3 processes of less developed regions. Regional Studies, $1-13$.

Berger, T. \& Bristow, G. (2009). Competitiveness and the Benchmarking of Nations - A critical reflection. In: International Advances in Economic Research, November 2009, https://doi.org/10.1007/s11294-009-9231-x

Boschma, R. (2015). Towards an evolutionary perspective on regional resilience. Regional Studies, 49(5), 733-751.

Boschma, R. (2014). Constructing regional advantage and smart specialisation: Comparison of two European policy concepts. Scienze Regionali.

Boschma, R.A. \& Ter Wal, A.L.J. (2007). Knowledge networks and innovative performance in an industrial district: The case of a footwear district in the South of Italy, Industry and Innovation, 14(2), 177-199. 


\section{ENTREPRENEURSHIP AND SUSTAINABILITY ISSUES}

ISSN 2345-0282 (online) http://jssidoi.org/jesi/

2020 Volume 8 Number 2 (December)

http://doi.org/10.9770/jesi.2020.8.2(80)

Make your research more visible, join the Twitter account of ENTREPRENEURSHIP AND SUSTAINABILITY ISSUES: @Entrepr69728810

Braun, V., \& Clarke, V. (2006). Using thematic analysis in psychology. Qualitative research in psychology, 3(2), 77-101.

Brugmann, J. (1997): Is there a method in our measurement? The use of indicators in local sustainable development planning. In: Local Environment - The International Journal of Justice and Sustainability, 2, 59-72. https://doi.org/10.1080/13549839708725512.

Capello, R., \& Kroll, H. (2016). From theory to practice in smart specialization strategy: emerging limits and possible future trajectories. Planning Studies, 24(8), 1393-1406.

Chesbrough, H. (2003). Open Innovation: The New Imperative for Creating and Profiting from Technology. Boston: Harvard Business School Press.

Cismas, L.M., Miculescu, A., Negrut, L., Negrut, V., Otil, M.D., \& Vadasan, I. (2019). Social Capital, Social Responsibility, Economic Behavior and Sustainable Economic Development - An Analysis of Romania's Situation. Transformations in Business \& Economics, $18(2 \mathrm{~A}(47 \mathrm{~A})), 605-627$.

Cohen, W. M., \& Levinthal, D. A. (1990). Absorptive capacity: A new perspective on learning and innovation. Administrative science quarterly, 128-152.

Cooke, P, \& Morgan, K. (1997). The Associated Economy: Firms Regions and Innovation. Oxford University Press.

Cooke, P. (2001). Regional innovation systems, clusters, and the knowledge economy. Industrial and corporate change, 10(4), 945-974. https://doi.org/10.1093/icc/10.4.945

Cooke, P. (2016). Four minutes to four years: the advantage of recombinant over specialized innovation-RIS3 versus 'smartspec'. European Planning Studies, 24(8), 1494-1510.

Courchene, T. J. (1995). Glocalisation: the regional / international interface. Canadian Journal of Regional Science, 18(1), 1-20.

Crabtree, B. F., \& Miller, W. L. (1992). Research methods for primary care. Doing Qualitative Research, 3.

Cvijanović, V., Griniece, E., Gulyás, O., Reid, A. \& Varga, H. (2020). Stakeholder engagement through entrepreneurial discovery? Lessons from countries and regions in Central and Eastern Europe, Cogent Social Sciences, 6(1),

https://doi.org/10.1080/23311886.2020.1794273

Del Castillo J., Barroeta B. Y \& Paton J. (2013): Entrepreneurial Discovery (ED) and Smart Specialisation: theory and reality. 12th International Entrepreneurial Forum. Vilnius - Lithuania. Retrieved from https://www.redalyc.org/pdf/5143/514351601001.pdf.

Dixon-Woods, M., Agarwal, S., Jones, D., Young, B. and Sutton, A. (2005). Synthesising qualitative and quantitative evidence: a review of possible methods. Journal of Health Services Research \& Policy, 10(1), 45-53B.

European Commission (2008). Knowledge for Growth. European Issues and Policy Challenges.

European Commission (2010). Europe 2020 Flagship Initiative Innovation Union, Communication from the Commission, October 06, 2010, from https://eur-lex.europa.eu/legal-content/EN/ALL/?uri=CELEX\%3A52010DC0546.

European Commission. (2014a). For a European Industrial Renaissance, Communication from the Commission to the European Parliament, the Council, the European Economic and Social Committee and the Committee of the Regions, COM(2014) 14 final. Brussels.

European Commission (2019a). The European Green Deal, Communication from the Commission, December 11, 2019, from https://eurlex.europa.eu/legal-content/EN/TXT/?qid=1588580774040\&uri=CELEX:52019DC0640 .

European Commission (2019b). Eurostat. Database last accessed on 25.10.2019.

Fagerberg, J., Mowery, D. C., \& Nelson, R. R. (Eds.). (2004). The oxford handbook of innovation. Oxford: Oxford University Press. 


\section{ENTREPRENEURSHIP AND SUSTAINABILITY ISSUES}

ISSN 2345-0282 (online) http://jssidoi.org/jesi/

2020 Volume 8 Number 2 (December)

http://doi.org/10.9770/jesi.2020.8.2(80)

Make your research more visible, join the Twitter account of ENTREPRENEURSHIP AND SUSTAINABILITY ISSUES: @Entrepr69728810

Farole, T., Rodriguez-Pose, A. \& Storper, M. (2011). Cohesion Policy in the European Union: Growth, Geography, Institutions, Journal of Common Market Studies, 49(5), 1089-1111. https://doi.org/10.1111/j.1468-5965.2010.02161.x

Fellnhofer K. (2017). Evidence revisited: Literature on smart specialisation calls for more mixed research designs, International Journal of Knowledge-Based Development, 8(3), 229-248.

Fereday, J., \& Muir-Cochrane, E. (2006). Demonstrating rigor using thematic analysis: A hybrid approach of inductive and deductive coding and theme development. International journal of qualitative methods, 5(1), 80-92.

Ferreira, F., \& Seixas, P. C. (2019). The Case for Smart Specialization Strategies (RIS3) as an Instrument for Place-Based Policies: Excavating the New Regional Development Paradigm. In Smart Specialization Strategies and the Role of Entrepreneurial Universities (pp. 131-152). IGI Global.

Ferenc, B., Tamás, G., Péter, M., István, M. \& László, S. (2013). Del-Alföld Intelligens Innovációs Szakosodási Stratégiája. Retrieved from: http://www.darinno.hu/wp-content/uploads/2015/01/2212-26-da_s3_v3_20130325_tars.egyeztetes.pdf.

Florida, R. (1995). Toward the Learning Region, Futures, 27(5), 527-536.

Foray, D., \& Van Ark, B. (2008). Overview on Knowledge for Growth: European issues and policy challenges, pp. 6-15. Office for Official Publications of the European Communities.

Foray, D., David, P. A., \& Hall, B. (2009). Smart specialisation - the concept. Knowledge economists policy brief, 9(85), 100.

Foray, D., David, P. A., \& Hall, B. H. (2011). Smart specialisation from academic idea to political instrument, the surprising career of a concept and the difficulties involved in its implementation (No. REP_WORK). EPFL.

Foray, D. (2012). Smart Specialisation: the Concept. Smart Specialisation Conference, Sofia (Bulgaria).

Foray, D., Goddard, J., Beldarrain, X.G., Landabaso, M., McCann, P., Morgan, K., Nauwelaers, C. and Ortega-Argil.s, R. (2012). Guide to Research and Innovation Strategies for Smart Specialisations (RIS3), European Commission, Luxembourg.

Foray D. \& Goenega X. (2013). The goals of smart specialisation. European Commission. JRC Scientific and Policy Report EUR 26005 EN 2013. Retrieved from http://ressources.aunege.fr/nuxeo/site/esupversions/efb22d92-ef97-4c7b-ac02eb9c6a86570c/res/ForayGoenaga2013.pdf.

Foray, D. (2014). From smart specialisation to smart specialisation policy. European Journal of Innovation Management, $17(4), 492-507$. https://doi.org/10.1108/EJIM-09-2014-0096

Fotakis, C., Rosenmöller, M., Brennan, J., Matei, L., Nikolov, R., Petiot, C., \& Puukka, J. (2014). The role of Universities and Research Organisations as drivers for Smart Specialisation at regional level. EU Directorate-General for Research and Innovation.

Gault, F. (2013): Handbook of Innovation Indicators and Measurement - Chapter 1: Innovation indicators and measurement: an overview. Retrieved from: https://doi.org/10.4337/9780857933652

Gertler, M. S., \& Levitte, Y. M. (2005). Local nodes in global networks: the geography of knowledge flows in biotechnology innovation. Industry and Innovation, 12(4), 487 - 507.

Gianelle, C. \& Kleibrink, A. (2015). Monitoring Mechanisms for Smart Specialisation Strategies, S3 Policy Brief Series No. 13/2015. JRC Technical Reports.

Gianelle, C. \& Kleibrink, A. (2016). Monitoring innovation and development strategies - Stakeholder involvement, learning and sustainable policy cycles, Governing Smart Specialisation.

Giannitsis, T. \& Kager, M. (2009). Technology and Specialization: Dilemmas, Options and Risks? Expert group 'Knowledge for Growth'.

Grillitsch, M. (2016). Institutions, smart specialisation dynamics and policy. Environment and Planning C: Government and Policy, 34(1), 22 -37. https://doi.org/10.1177/0263774X15614694. 


\section{ENTREPRENEURSHIP AND SUSTAINABILITY ISSUES}

ISSN 2345-0282 (online) http://jssidoi.org/jesi/

2020 Volume 8 Number 2 (December)

http://doi.org/10.9770/jesi.2020.8.2(80)

Make your research more visible, join the Twitter account of ENTREPRENEURSHIP AND SUSTAINABILITY ISSUES: @Entrepr69728810

Griniece, E., Panori, A., Kakderi, C., Komninos, A. \& Reid, A. (2017). Methodologies for Smart Specialisation Strategies: A View across the EU regions, Proceedings of International Conference for Entrepreneurship, Innovation and Regional Development, pp. 321- 330, 31.08.-01.09.2017, Thessaloniki, Greece.

Guzzo, F. \& Perianez-Forte, I. (2019). Smart Specialisation at work: evidences from Peer eXchange and Learning workshops. JRC Technical Reports. European Commission. December 2019. https://doi.org/10.1080/09654313.2016.1181717

Hayek, F.A. (2002). Competition as a Discovery Procedure, The Quarterly Journal of Austrian Economics, 5(3), 9-23.

Hollanders, H.; Sadki, N. \& Merkelbach, I. (2019). The Regional Innovation Scoreboard.

Kempton, L., Goddard, J., Edwards, J., Hegyi, F. B., \& Elena-Pérez, S. (2013). Universities and smart specialisation. S3 Policy Brief Series, 3 .

Khan, S., Maqbool, A., Haleem, A., \& Khan Mohd, I. (2020). Analyzing critical success factors for a successful transition towards circular economy through DANP approach. Management of Environmental Quality: An International Journal, 31(3), 505-529.

https://www.emerald.com/insight/content/doi/10.1108/MEQ-09-2019-0191/full/html

Kitchin, R., Laurialt T.P. \& McArdle, G. (2015) Knowing and governing cities through urban indicators, city benchmarking and real-time dashboards. In: Regional Studies, Regional Science, 2, 6-28. https://doi.org/10.1080/21681376.2014.983149.

Kleibrink, A., Gianelle, C. \& Doussineau, M. (2016). Monitoring innovation and territorial development in Europe: emergent strategic management. European Planning Studies, 48(8), 1438-1458.

Kleibrink, A., \& Magro, E. (2018). The making of responsive innovation policies: varieties of evidence and their contestation in the Basque Country. Palgrave Communications, 4(1) https://doi.org/10.1057/s41599-018-0136-2

Kohrgruber, K. (s.a.). Economic Strategy Styria 2025. Retrieved from: https://s3platform.jrc.ec.europa.eu/regions/at22/tags/at22.

Krammer, S. (2017). Science, technology, and innovation for economic competitiveness: The role of smart specialization in less-developed countries, Technological Forecasting \& Social Changes, 123, 95-107. http://dx.doi.org/10.1016/j.techfore.2017.06.028

Kroll, H., Muller, E., Schnabl, E. \& Zenker, A. (2014). From Smart Concept to Challenging Practice - How European Regions Deal with the Commision's Reqquest for Novel Innovation Strategies, Working Papers Firms and Region No. R2/2014.

Kroll, H. (2015). Efforts to Implement Smart Specialization in Practice-Leading Unlike Horses to the Water, European Planning Studies, 23(10), 2079-2098. https://doi.org/10.1080/09654313.2014.1003036

Kroll, H. (2019). Eye to eye with the innovation paradox: why smart specialization is no simple solution to policy design, European Planning Studies, 27(5), 932-951. https://doi.org/10.1080/09654313.2019.1577363

Kuznetsov, Y., \& Sabel, C. (2017). Managing self-discovery: Diagnostic monitoring of a portfolio of projects and programs. In Advances in the Theory and Practice of Smart Specialization, pp. 51-72. Academic Press. https://doi.org/10.1016/B978-0-12-804137-6.00003-6

Landabaso, M. (2014). Guest editorial on research and innovation strategies for smart specialisation in Europe. European Journal of Innovation and Management, 17(4), 378-389. https://doi.org/10.1108/EJIM-08-2014-0093

Larosse, J. (2013). The discovery of smart specialisation. REGLAB Smart Regions Seminar.

Larosse, J., Corpakis, D. \& Tuffs, R. (2020). The Green Deal and Smart Specialisation, Version 4, February 20.

Larrea, M., Estensoro, M. \& Pertoldi, M. (2019). Multilevel governance for Smart Specialisation: basic pillars for its construction, JRC Technical Reports. https://doi.org/10.2760/425579

Lopez-Rodriguez, J., \& Martínez López, D. (2014). Beyond the R\&D effects on innovation: the contribution of non-R\&D activities to TFP growth in the EU. IEB Working Paper 2014/16. 


\section{ENTREPRENEURSHIP AND SUSTAINABILITY ISSUES}

ISSN 2345-0282 (online) http://jssidoi.org/jesi/

2020 Volume 8 Number 2 (December)

http://doi.org/10.9770/jesi.2020.8.2(80)

Make your research more visible, join the Twitter account of ENTREPRENEURSHIP AND SUSTAINABILITY ISSUES: @Entrepr69728810

Maes J., Liquete C., Teller A., Erhard M., Paracchini M.L., Barredo J.I., Grizzetti B., Cardoso A., Somma F., Petersen J.E., Meiner A., Gelabert E.R., Zal N., Kristensen P., Bastrup-Birk A., Biala K., Piroddi C., Egoh B., Degeorges P. \& Fiorina C. (2016). An indicator framework for assessing ecosystem services in support of the EU Biodiversity Strategy to 2020. In: Ecosystem Services, Vol. 17, pp. 14 23.

Magro, E., Navarro, M., \& Zabala-Iturriagagoitia, J. M. (2014). Coordination-mix: The hidden face of STI policy. Review of Policy Research, 31(5), 367-389.

Magro, E. \& Wilson, J.R. (2013). Complex innovation policy systems: Towards an evaluation mix. In: Research Policy, 42(9), $1647-1656$. http://dx.doi.org/10.1016/j.respol.2013.06.005

Malerba, F. (2005). Sectoral systems of innovation: a framework for linking innovation to the knowledge base, structure and dynamics of sectors, Economics of Innovation and New Technologies, 14(1-2), 63-83.

Masana, R. E., \& Fernández, T. (2019). Monitoring S3: Key dimensions and implications. Evaluation and program planning, 77, 101720. https://doi.org/10.1016/i.evalprogplan.2019.101720

Matusiewicz, A. (2012). Regional Innovation Strategy oft he Slaskie Voivodeship - for the years 2013 - 2020. Retrieved from: https://s3platform.jrc.ec.europa.eu/regions/pl22/tags/pl22

Mazzanti, M., Mazzarano, M., Pronti, A., Quatrosi, M. (2020). Fiscal policies, public investments and wellbeing: mapping the evolution of the EU. Insights into Regional Development, 2(4), 725-749. http://doi.org/10.9770/IRD.2020.2.4(1)

Mazzoni, F. (2020). Circular economy and eco-innovation in Italian industrial clusters. Best practices from Prato textile cluster. Insights into Regional Development, 2(3), 661-676. https://doi.org/10.9770/IRD.2020.2.3(4)

Mazzucato, M. (2014). A mission-oriented approach to building the entrepreneurial state. A 'Think Piece'for the Innovative UK. Technology Strategy Board: London, UK

McCann P. \& Ortega-Argilés R. (2011): Smart Specialisation, Regional Growth and Applications to EU Cohesion Policy ECONOMIC GEOGRAPHY WORKING PAPER 2011: FACULTY OF SPATIAL SCIENCES, UNIVERSITY OF GRONINGEN. Retrieved from http://diposit.ub.edu/dspace/handle/2445/116560.

Ministry of Education and Science of the Republic of Lithuania (2010): Education in Lithuania. Derived from: https://www.sac.smm.lt/wpcontent/uploads/2016/02/Education_2010_eurosh.pdf

McCann, P. \& Ortega-Argilés, R. (2013). Modern regional innovation policy, Cambridge Journal of Regions, Economy and Society. https://doi.org/10.1093/cjres/rst007

McCann, P. \& Ortega-Argilés, R. (2015). Smart Specialization, Regional Growth and Applications to European Union Cohesion Policy, Regional Studies, 49(8), 1291 - 1302, https://doi.org/10.1080/00343404.2013.799769

McCann, P., \& Ortega-Argilés, R. (2016a). Smart specialisation, entrepreneurship and SMEs: issues and challenges for a results-oriented EU regional policy. Small Business Economics, 46(4), 537-552.

McCann, P. \& Ortega-Argilés, R. (2016b). The early experience of smart specialization implementation in EU cohesion policy, European Planning Studies, 24(8), 1407-1427. https://doi.org/10.1080/09654313.2016.1166177

McCann, P. \& Ortega-Argilés, R. (2016c). Smart Specialisation: Insights from the EU Experience and Implications for Other Economies, Journal of Regional Research, 36, 279-293.

Mehta, P., Singh, M., \& Mittal, M. (2019). It is not an investment if it is destroying the planet: A literature review of socially responsible investments and proposed conceptual framework. Management of Environmental Quality: An International Journal, 31(2), 307-329. https://www.emerald.com/insight/content/doi/10.1108/MEQ-08-2019-0176/full/html 


\section{ENTREPRENEURSHIP AND SUSTAINABILITY ISSUES}

ISSN 2345-0282 (online) http://jssidoi.org/jesi/

2020 Volume 8 Number 2 (December)

http://doi.org/10.9770/jesi.2020.8.2(80)

Make your research more visible, join the Twitter account of ENTREPRENEURSHIP AND SUSTAINABILITY ISSUES: @Entrepr69728810

Morgan, K. (2017). Nuturing novelty: Regional innovation policy in the age of smart specialisation, Environment and Planning C: Politics and Space, 35(4), 569-583. https://doi.org/10.1177/0263774X16645106.

Navarro, M., Gibaja, J., Franco, S., Murciego, A., Gianelle, C., Hegyi, F. \& Kleibrink, A. (2014). Regional benchmarking in the smart specialisation process: Identification of reference regions based on structural similarity. S3 Working Paper Series No. 03/2014, JRS Technical Reports.

OECD (2019). Innovation-driven Growth in Regions: The Role of Smart Specialisation. Retrieved from http://www.oecd.org/sti/inno/smartspecialisation.htm.

Paliokaite, A., Martinaitis, Z. \& Reimeris, R. (2015). Foresight methods for smart specialisation strategy development in Lithuania, Technological Forecasting \& Social Change, 101, 185-199. http://dx.doi.org/10.1016/j.techfore.2015.04.008

Panori, A., Komninos, N., Kakderi, C. \& Fellnhofer, K. (2017). Smart Specialisation Strategies: An online platform for strategy design and assessment. RelStat 2017. Springer Lecture Notes in Networks and Systems.

Panori, A., Kakderi, C., Komninos, N., Fellnhofer, K., Reid, A. \& Mora, L. (2020). Smart systems of innovation for smart places: Challenges in deploying digital platform for co-creation and data-intelligence, Land Use Policy,

https://doi.org/10.1016/j.landusepol.2020.104631.

Pavitt, K. (1984). Sectoral patterns of technical change: towards a taxonomy and a theory, Research Policy, 13, $343-373$.

Piirainen, K., Tanner, A.N. \& Alkaersig, L. (2017). Regional foresight and dynamics of smart specialization: A typology of regional diversification patterns, Technological Forecasting \& Social Change, 115, 289-300. http://dx.doi.org/10.1016/j.techfore.2016.06.027

Pires, S.M., Polido, A., Teles, F., Silva, P. \& Rodrigues, C. (2019). Territorial innovation models in less developed regions in Europe: the quest for a new research agenda? European Planning Studies. https://doi.org/10.1080/09654313.2019.1697211

Porter, M. (2000). Location, Competition and Economic Development: Local Networks in a Global Economy, Economic Development Quarterly, 14 (1), 15-34.

Prause. G. (2014). Smart Specialisation and EU Eastern Innovation Cooperation: A Conceptual Approach. Baltic Journal of European Studies Tallinn University of Technology, 4, (1 (16)). https://doi.org/10.2478/bjes-2014-0001.

Prause, G. \& Thurner, T. (2014). User Communities - Drivers for Open Innovation, Foresight - Russia, 8(1), $24-32$.

Rajnoha, R., Lesnikova, P., Stefko, R., Schmidtova, J., \& Formanek, I. (2019). Transformations in Strategic Business Planning in the Context of Sustainability and Business Goals Setting. Transformations in Business \& Economics, (18 (47)), 44-66.

Ranga, M. (2018) Smart specialization as a strategy to develop early-stage regional innovation systems, European Planning Studies, 26 (11), 2125 - 2146. https://doi.org/10.1080/09654313.2018.1530149

Regione del Veneto (2015). Smart Specialisation Strategy della Regione del Veneto. Retrieved from: https://s3platform.jrc.ec.europa.eu/regions/ith3/tags/ith3.

Regione Piemonte (2016). Strategia per la specializzazione intelligente der Piemonte. Retrieved from: https://s3platform.jrc.ec.europa.eu/regions/itc1/tags/itc1.

Republika Slovenija (2014). Smart Specialisation Strategy of the Republic of Slovenia. Retrieved from: https://s3platform.jrc.ec.europa.eu/regions/si/tags/si.

Rickman, D. \& Schwer, R. (1995). “A comparison of the multipliers of IMPLAN, REMI and RIMS II: Benchmarking ready-made models for comparison”. In: The Annals of Regional Science, 29, 363-374. https://doi.org/10.1007/BF01581882

Rodríguez-Pose, A \& Wilkie, C. (2014). Institutions and the Entrepreneurial Discovery Process for Smart Specialisation, Papers in Evolutionary Economic Geography, 15.23, Utrecht University. 


\section{ENTREPRENEURSHIP AND SUSTAINABILITY ISSUES}

ISSN 2345-0282 (online) http://jssidoi.org/jesi/

2020 Volume 8 Number 2 (December)

http://doi.org/10.9770/jesi.2020.8.2(80)

Make your research more visible, join the Twitter account of ENTREPRENEURSHIP AND SUSTAINABILITY ISSUES: @Entrepr69728810

Scheerens, J. (2012). Perspectives on Education Quality, Education Indicators and Benchmarking.

Schumpeter, J. (1947). Innovation: the creative impulse. Journal of Economic History, Vol. 7(2), pp. 149 - 59.

Schwemlein S., Cronk R. \& Bartram J. (2016). Indicators for Monitoring Water, Sanitation and Hygiene: A Systematic Review of Indicator Selection Methods. International Journal of Environmental Research and Public Health, 16, https://doi.org/10.3390/ijerph13030333

Shahin A. \& Ali Mahbod M. (2007). „An integration of analytical hierarchy process and goal setting”. In: International Journal of Productivity and Performance Management. 56(3), 236-240. https://doi.org/10.1108/17410400710731437

Smith, K. (2000). Innovation as a systemic phenomenon: rethinking the role of policy, Enterprise and Innovation Management Studies, $1(1), 73-102$.

Sosnowski, S., Hetman, K., Grabczuk, K., Cholewa, M., Sobczak, J., Pękalski, T., Walasek, A., Mocior, E., Habza, A., Janczarek, P., Bartuzi, K., Bożeński, E., Bryda, K., Byzdra, I., Donica, D., Franaszek, P., Kawałko, B., Nakielska, I., Orzeł, Z., Pieczykolan, A., Rudnicki, W., Sokół, M., Struski, S. \& Szych, H. (2014). Ragional Innovation Stratgey for the Lubelskie Voivodeship 2020 - Regional Innovation Strategy for Smart Specialisation (RIS3). Retrieved from: https://s3platform.jrc.ec.europa.eu/regions/pl31/tags/pl31.

Sotarauta, M. (2018). Smart Specialisation, Shared Vision and Policy Traps. Sente Working Papers, 40.

Strategierat Wirtschaft - Wissenschaft (2014). Regionale Innovationsstrategie 2020 für das Land Mecklenburg-Vorpommern. Retrieved from https://s3platform.jrc.ec.europa.eu/regions/de8/tags/de8.

Tiits, M., Kalvet, T., \& Mürk, I. (2015). Smart specialisation in cohesion economies. Journal of the Knowledge Economy, 6(2), $296-319$.

Thomas, G. (2011). A typology for the case study in social science following a review of definition, discourse, and structure. Qualitative inquiry, 17(6), 511-521.

Tödtling, F., Lehner, P. \& Trippl, M. (2006). Innovation in knowledge intensive industries: The nature and geography of knowledge links, European Planning Studies, 14(8), 1035-1058.

Vezzani A., Baccan M., Candu A., Castelli A., Dosso M., Gkotsis P. (2017). Smart Specialisation, seizing new industrial opportunities. JRC Technical Report, European Commission. https://doi.org/10.2760/485744

Virkkala, S., Mäenpää, A., \& Mariussen, Å. (2017). A connectivity model as a potential tool for smart specialization strategies. European Planning Studies, 25(4), 661-679.

Wolfe, D. (2002). Social Capital and Cluster Development in Learning Regions. In: J. A. Holbrook \& D. Wolfe (Eds.). Knowledge, Clusters and Regional Innovation: Economic Development in Canada, Montreal and Kingston, London, Ithaca: School of Policy Studies, Queens University, pp. 11-38.

Woronowicz, T., Boronowsky, M., Wewezer, D., Mitasiunas, A., Seidel, K. \& Cotera, I.R. (2017). Towards a Regional Innovation Strategies Modelling, Proceedia Computer Science, 104, 227-234. https://doi.org/10.1016/j.procs.2017.01.118

Yazday J., Panopalis P., Gillis J.Z., Schmajuk G., MacLean C.H., Wofsy D. \& Yelin E. (2009). A Quality Indicator Set for Sytematic Lupus Erythematosus. In: Arthritis \& Rheumatism (Arthritis Care \& Research). 61(3), 370-377. https://doi.org/10.1002/art.24356

Yin, R. K. (2011). Applications of case study research. sage.

Yin, R. K. (2009). Case Study Research: Design and, London: Sage Publications. 
ENTREPRENEURSHIP AND SUSTAINABILITY ISSUES

ISSN 2345-0282 (online) http://jssidoi.org/jesi/

2020 Volume 8 Number 2 (December)

http://doi.org/10.9770/jesi.2020.8.2(80)

Make your research more visible, join the Twitter account of ENTREPRENEURSHIP AND SUSTAINABILITY ISSUES: @Entrepr69728810

\section{Acknowledgements}

This research was supported by the Interreg project "SMART_watch"project that was implemented in the frame of the Interreg Central Europe Programme 2014-2020 from June 2017 to May 2020. The project is based on the research and practical gaps highlighting the needs to support and enhance monitoring capacity of the regions in terms of Smart Specialisation.
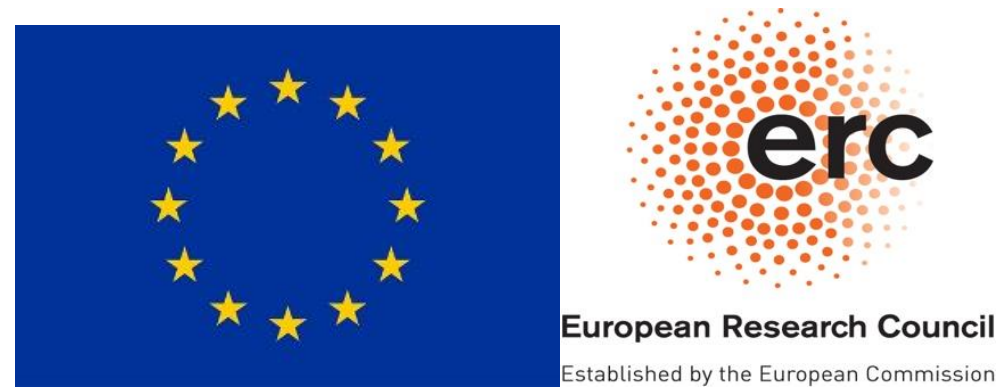

Short biographical note about the contributors at the end of the article (name, surname, academic title and scientific degree, duties, research interests):

Laima GERLITZ, PhD. Laima Gerlitz is a researcher at Wismar University of Applied Sciences: Technology, Business and Design and PhD Student at Tallinn University of Technology within the fields of project, design and transport related management. Since 2014, Laima Gerlitz is researching on her PhD topic "Design as Success Factor for Innovation, Competitiveness and Smart Growth". Key fields of research are design and innovation, strategic design management, design management for enterprises, competitiveness and value creation deriving from design-driven approaches in organisational settings, particularly in the context of small manufacturing and high-tech enterprises and start-ups.

ORCID ID: orcid.org/0000-0002-7127-7678

Christopher MEYER, M.Sc. Christopher Meyer coordinates several European research projects at the European Project Center associated to the University of Wismar. After his master degree in public economics, he started his studies as PhD Candidate at TalTech University in Tallinn, Estonia, elaborating the impact of Smart Specialisation on the Blue Economy of the Baltic Sea Area.

ORCID ID: orcid.org/0000-0002-6048-1198

Prof. Dr. Gunnar PRAUSE is a professor at the Tallinn School of Economics and Business Administration at Tallinn University of Technology (TU) Tallinn in Estonia as well as at Hochschule Wismar, University of Applied Sciences: Technology, Business and Design in Wismar, Germany. Professor Gunnar Prause has published widely internationally and has many years of experience in carrying out national and European (research) projects.

ORCID ID: orcid.org/0000-0002-3293-1331

Copyright (C) 2020 by author(s) and VsI Entrepreneurship and Sustainability Center

This work is licensed under the Creative Commons Attribution International License (CC BY).

http://creativecommons.org/licenses/by/4.0/

c) (7) Open Access 